I N T ER N ATIONAL MONETARY FUND

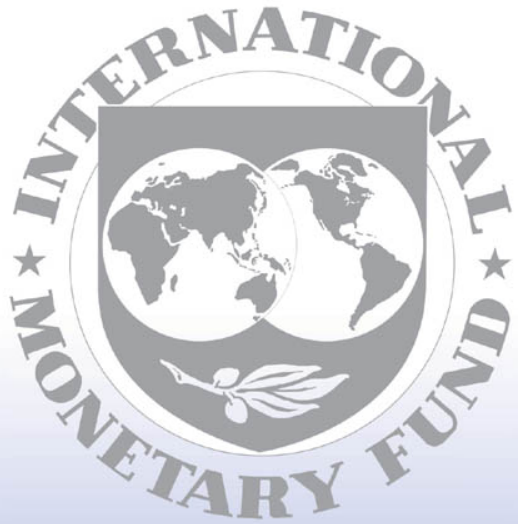

Staff

Country

Reports 
Islamic Republic of Mauritania: 2006 Article IV Consultation-Staff Report; Staff Statement; Public Information Notice and Press Release on the Executive Board Discussion; and Statement by the Executive Director for the Islamic Republic of Mauritania

Under Article IV of the IMF's Articles of Agreement, the IMF holds bilateral discussions with members, usually every year. In the context of a combined discussion of the 2006 Article IV consultation with the Islamic Republic of Mauritania, first assessment of the staff-monitored program, and assessment of qualification for the Multilateral Debt Relief Initiative, the following documents have been released and are included in this package:

- the staff report for the 2006 Article IV consultation, First Assessment of the Staff-Monitored Program, and Assessment of Qualification for the Multilateral Debt Relief Initiative prepared by a staff team of the IMF, following discussions that ended on May 9, 2006, with the officials of Mauritania on economic developments and policies. Based on information available at the time of these discussions, the staff report was completed on June 7, 2006. The views expressed in the staff report are those of the staff team and do not necessarily reflect the views of the Executive Board of the IMF.

- $\quad$ a staff statement of June 21, 2006 updating information on recent developments.

- $\quad$ a Public Information Notice (PIN) and Press Release summarizing the views of the Executive Board as expressed during its June 21, 2006 discussion of the staff report that concluded the Article IV consultation, and assessment of qualification for the Multilateral Debt Relief Initiative, respectively.

- $\quad$ a statement by the Executive Director for the Islamic Republic of Mauritania.

The document listed below has been or will be separately released.

\section{Statistical Appendix}

The policy of publication of staff reports and other documents allows for the deletion of market-sensitive information.

To assist the IMF in evaluating the publication policy, reader comments are invited and may be sent by e-mail to publicationpolicy@imf.org.

Copies of this report are available to the public from

International Monetary Fund • Publication Services

$70019^{\text {th }}$ Street, N.W. $\bullet$ Washington, D.C. 20431

Telephone: (202) 623-7430 • Telefax: (202) 623-7201

E-mail: publications@imf.org Internet: http://www.imf.org

Price: $\$ 15.00$ a copy

\section{International Monetary Fund Washington, D.C.}


INTERNATIONAL MONETARY FUND

ISLAMIC REPUBLIC OF MAURITANIA

\section{Staff Report for the 2006 Article IV Consultation, First Assessment of the Staff-Monitored Program, and Assessment of Qualification for the Multilateral Debt Relief Initiative}

Prepared by the Staff Representatives for the 2006 Consultation with Mauritania

Approved by Amor Tahari and Anthony R. Boote

June 7, 2006

- Discussions were held in Nouakchott from April 26 to May 9, 2006. The staff team consisted of Messrs. Le Dem (head), Loko, Wieczorek, and Ms. Hijazi (all MCD), Mr. Meier (PDR) and Mr. Callier, the Fund resident representative.

- The mission met with Governor Ould Zeidane (Central Bank of Mauritania), Ministers Ould Abed (Economic Affairs and Development) and Ould Cheikh Sidiya (Finance), other cabinet members and government officials, and representatives of the business sector, civil society organizations, and development partners. Mr. Sidi Bouna, Senior Advisor to the Executive Director, attended most of the meetings.

- Following the new authorities' decision to resolve the data issues that had plagued the relations with the Fund since early 2004, Mauritania embarked on a six-month staff-monitored program (SMP) covering the first half of 2006 (Country Report 06/255). Successful implementation of the SMP would pave the way for a new Poverty Reduction and Growth Facility (PRGF) supported program. In the attached letter (Attachment I) the authorities inform the Managing Director of the progress in implementing the SMP and of the preparation for the new program.

- On March 27, 2006, the Executive Board determined that Mauritania would be expected to repay two noncomplying disbursements under the 1999-2002 PRGF arrangement (SDR 12.14 million plus accrued interest) in two installments by June 15, 2006. The first installment (SDR 2 million plus accrued interest) was paid on April 26, 2006, as expected.

- In December 2005, Executive Directors agreed that to qualify for the Multilateral Debt Relief Initiative (MDRI), in addition to the resolution of data issues, Mauritania needed to implement six months of sound macroeconomic policies and other remedial actions in the areas of budget formulation, execution, and reporting. All these conditions have been met.

- Mauritania accepted the obligations of Article VIII, Sections 2 (a), 3, and 4 in 1999, but still maintains foreign exchange rationing, which constitutes an exchange restriction under Section 2 (a). Since 2003, the official exchange rate has been de facto pegged to the U.S. dollar, with a minor adjustment to the parity in October 2005.

- Despite shortcomings in the national accounts and balance of payments statistics, data provision to the Fund is now broadly adequate for surveillance purposes. 
Contents

Page

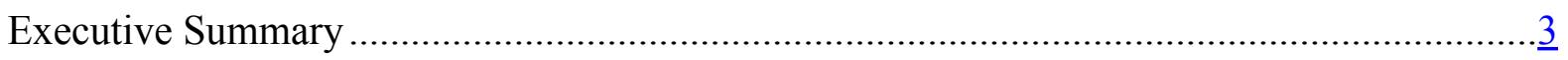

I. Background and Reassessment of Past Economic Performance ......................................... 4

II. Recent Developments and Short-Term Outlook ...................................................... 9

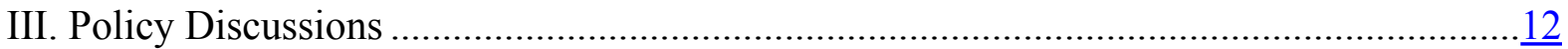

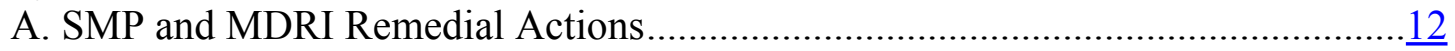

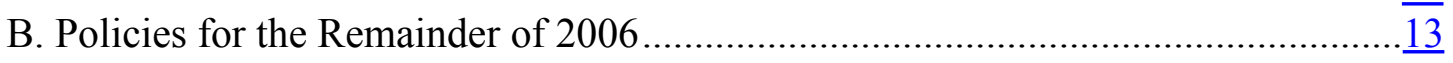

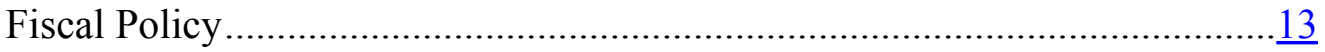

Monetary and Exchange Rate Policy ......................................................14

C. External Sector Policies .............................................................................. $\frac{15}{16}$

D. Financial Sector Reforms............................................................................ $\frac{16}{16}$

E. Poverty Reduction Strategy and the Medium-Term Framework ...........................

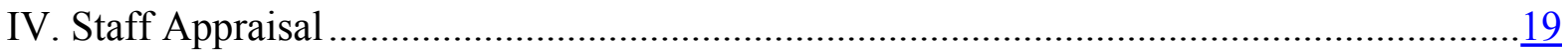

Tables

1. Selected Economic and Financial Indicators, 2001-06 ......................................22

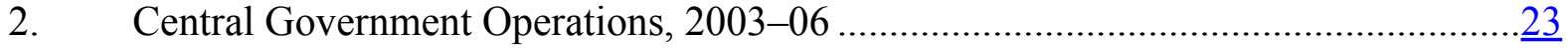

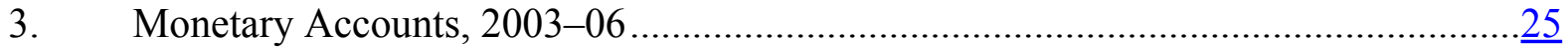

4. Balance of Payments, 2003-11 ....................................................................

5. Quantitative Indicators for the Staff-Monitored Program at end-March and end-June 2006 $\frac{27}{28}$

6. Structural Indicators for the Staff-Monitored Program, January-June 2006..............28

7. Remedial Actions for MDRI Qualification..........................................................29

8. Millennium Development Goals, 1990-2015 .................................................. $\frac{30}{31}$

9. Macroeconomic Framework, 2001-11 …............................................................. $\frac{31}{32}$

10. Public and Publicly Guaranteed (PPG) External Debt and Debt Relief, 2004-07 ....... $\underline{32}$

Figures

1. Data Revisions, 1994-2004 ..........................................................................

2. Income Velocity of Broad Money, 1992-2004 ….................................................

3. Monetary Developments and Exchange Rate Indices ..........................................10

\section{Boxes}

1. Causes, Consequences, and Lessons of a Prolonged Misreporting ............................. $\underline{8}$

2. Preliminary Findings of the FSAP Mission .................................................... 17

Appendices

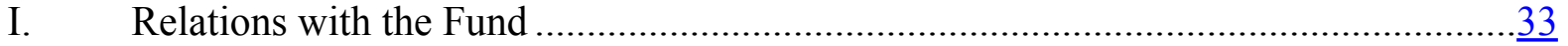

II. Relation with the World Bank Group .........................................................

III. Statistical Issues .................................................................................... 


\section{EXECUTIVE SUMMARY}

The transition authorities, in power since August 2005, have implemented an impressive policy shift toward transparency and good governance and have resolved the data issues. The revisions of most economic and financial data since 1992 confirmed that over many years fiscal and monetary policies had been substantially looser than previously reported to the Fund.

Since the last quarter of 2005, the authorities have embarked on sound macroeconomic policies and structural reforms. The elimination of extra-budgetary spending and central bank financing of the budget were instrumental in limiting the government deficit. As a result, inflation fell to single-digit levels over the last quarter of 2005 and official reserves started to rebound. Mauritania's external outlook and growth prospects took a boost from the start of oil production in February 2006.

The staff-monitored program (SMP) covering the first half of 2006 is firmly on track. Quantitative targets for end-March 2006 and structural indicators through May 2006 have all been realized. Mauritania has achieved progress in the area of public finance management (PFM), through the preparation of a medium-term expenditure framework ahead of the budget preparation cycle, stricter budget execution, and improved reporting and tracking of poverty reducing spending. The creation of the National Hydrocarbon Revenue Fund, which is now operational, marked a key step toward a transparent management of oil revenues.

\section{Staff considers that Mauritania has met all the criteria for MDRI qualification,} including the resolution of the data issues, six months of satisfactory macroeconomic performance (October 2005-March 2006), and implementation of the PFM remedial actions. Broad consultations are under way on a new poverty reduction strategy for 2006-10.

The authorities remain committed to the original 2006 budget spending limits and intend to use the projected additional oil revenue for reducing domestic government debt. This will also help the central bank achieve a significant build-up of official reserves, while preparing the conditions for a successful liberalization of the foreign exchange system. Staff welcomes the authorities' plan to eliminate the foreign exchange rationing by October 2006 and move to a more flexible exchange rate regime.

Satisfactory implementation of the SMP through end-June 2006 would pave the way for a new PRGF-supported program. The program should be based on further strengthening of data collection and reporting procedures, and focus on a growth-enhancing framework of sound macroeconomic policies and financial sector, trade, and governance reforms. The medium-term fiscal framework should rely on a prudent use of oil revenue, consistent with ambitious but realistic growth and poverty reduction objectives, and a manageable degree of real exchange rate appreciation. 


\section{Background and Reassessment of Past Economic Performance}

1. The Mauritanian transition authorities, who took power in the aftermath of the military coup last August, have initiated a democratization process that receives increasing support from the international community. Steps toward democracy include a referendum on constitutional amendments in June 2006, parliamentary elections in November 2006, and presidential elections in March 2007. The new parliament and government are expected to be in place by May 2007. The transition authorities decided to put transparency and good governance at the center of their program of economic stabilization and structural reforms and, accordingly, have revised the data that had been provided to the Fund to present a more accurate account of Mauritania's economic performance since 1992.

2. The authorities have prepared a preliminary report on economic performance during 1992-2004 covering all sectors of the economy. ${ }^{1}$ The revisions (Figure 1) mostly concern government expenditure, revealing the previously omitted large extra-budgetary outlays. The external trade data were corrected for significant underreporting of import values. All these revisions have been incorporated in the national accounts, but their effects on real GDP growth data and inflation indicators appear limited.

\section{The revised fiscal data confirm staff's assessment of a year ago that} Mauritania's past fiscal policy might have been substantially looser than previously reported to the Board. Fiscal accounts now show substantial fiscal deficits (exceeding 10 percent of GDP in 2001 and 2003), which were largely financed through advances from the Central Bank of Mauritania (BCM) and accumulation of payment arrears. Large extrabudgetary expenditure, ranging from 5 percent of GDP early on to more than 20 percent of GDP in 2003, were the main element missing in the original fiscal data. Extra-budgetary military expenditure, which reached $3 \frac{1}{2}$ percent of GDP per annum in 2003-04 (bringing military spending to four times the levels envisaged in the annual budgets), represented the largest identified component of these outlays. Other big items included spending on goods and services, supplementary allocations for embassies and, in 2003-04, drought-related expenditure. ${ }^{2}$ One third of extrabudgetary spending remains to be fully identified.

\footnotetext{
${ }^{1}$ The horizon of the revisions varies across sectors depending on the availability of the sources and the nature of the data (e.g., stocks versus flows); a broadly consistent set of data has been provided for 1994-2004.

2 During the 2005 Article IV consultation discussions, the authorities reported extra budgetary expenditure in 2003-04 equivalent to 55 percent of GDP over 18 months. The revised data show that extra budgetary outlays increased substantially in 2003-04 but to a lesser degree than reported in 2005 (reaching 33 percent of GDP over 24 months).
} 
Figure 1. Mauritania: Data Revisions, $1994-2004^{1}$
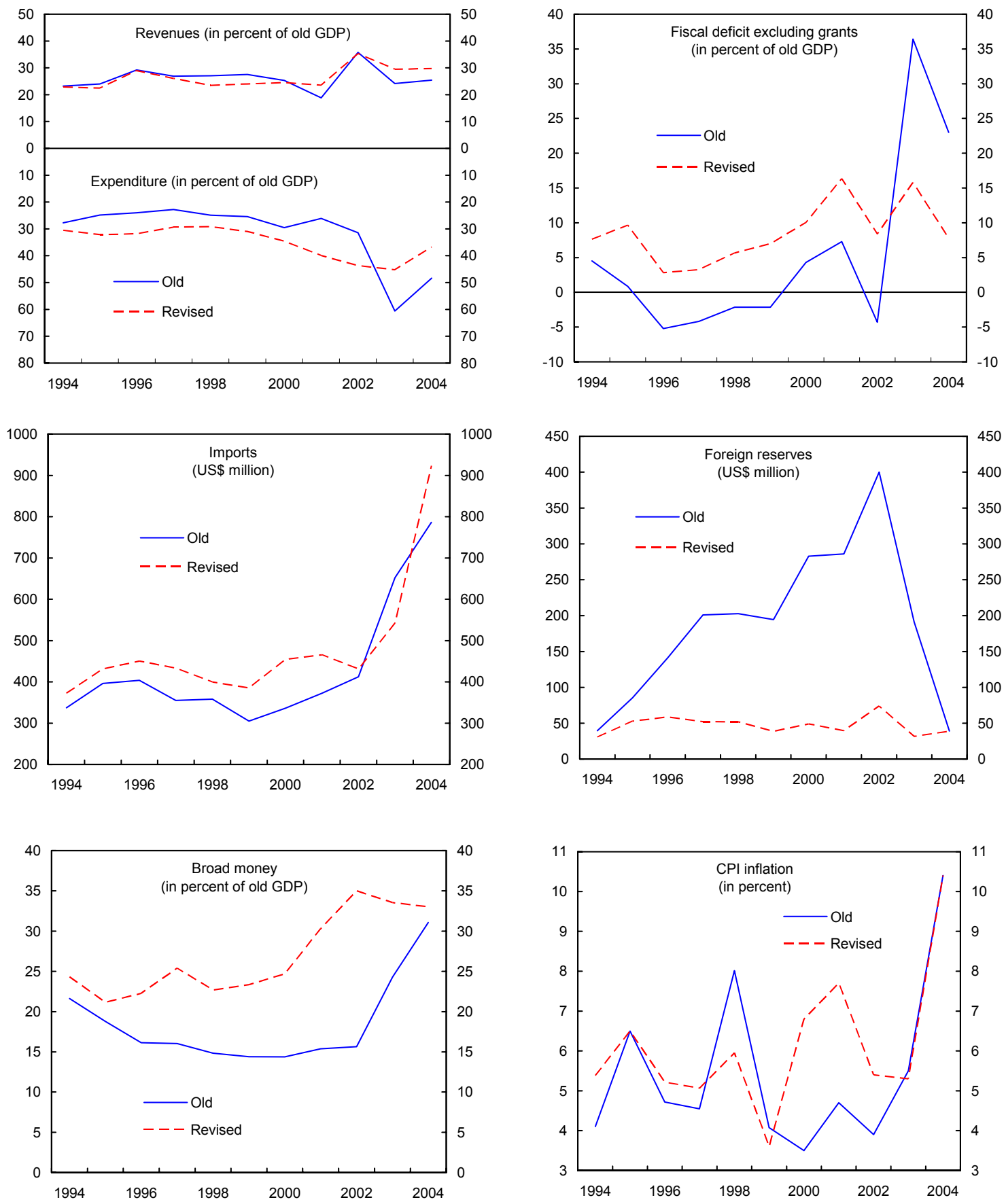

Source: Mauritanian authorities.

1 "Old" series refer to the data that were communicated to staff during the 2005 Article IV consultation discussions; "Revised" series refer to the 1994-2004 data that were communicated to staff between November 2005 and May 2006. 


\section{Revised BOP data reveal the chronic weakness of Mauritania's external} position. The main revisions show higher imports of goods and services, implying weaker trade and current account balances throughout the period. Customs understated the level of imports over much of the period by using artificially low reference prices instead of transaction prices for sensitive imports (e.g., sugar and wheat); this effect on the trade balance is partly offset by the estimation for the first time of Mauritania's informal reexports.

5. The new fiscal and external sector figures appear broadly consistent with the revised monetary and foreign reserves data that were provided to staff in November 2005. These data showed broad money growing at 15 percent per annum throughout the 1994-2002 period (more than twice as fast as implied by the originally reported data) and foreign reserves fluctuating around an average of some US\$50 million instead of growing steadily to reach nearly US $\$ 400$ million by end-2002. ${ }^{3}$

\section{Despite the substantial upward revision to money growth, CPI revisions are} marginal with a broadly neutral overall cumulative effect. Inflation figures have been revised downward by nearly one percentage point for 1993-99 and upward by two percentage points for 2000-03, leaving the annual average for the entire period broadly unchanged at some $5 \frac{1}{2}$ percent. The authorities affirmed that the new harmonized CPI (introduced in mid-2003) had been reported correctly. The retroactive correction of price indices led to an upward revision of the 2000 poverty indicators (e.g., the poverty headcount rose from 46.7 percent to 51 percent of population).

7. Revised national accounts, reflecting the revised fiscal, balance of payments, and CPI data, as well as methodological refinements, produced a downward revision to the average annual growth performance over the period. ${ }^{4}$ According to the revised figures, real GDP during 1993-2003 grew on average by slightly above 3 percent per annum instead of $4 \frac{1}{2}$ percent.

8. The data issues that were raised in the past have been resolved. ${ }^{5} \mathrm{~A}$ few developments need further explanation, including inflation, the remaining (although much more subdued than suggested by the 2005 Article IV consultation data) instability in the income velocity of broad money (Figure 2), and the apparent low income elasticity of imports (in U.S. dollar terms).

\footnotetext{
${ }^{3}$ The comparisons are made with respect to the data communicated to the Fund staff prior to September 2004.

${ }^{4}$ The main change concerns the level of the value added of the fishing sector, which is revised up following a new methodology for estimating intermediate consumption.

${ }^{5}$ See Country Report 06/255, paragraphs $2-3$ for details.
} 
Figure 2. Mauritania: Income Velocity of Broad Money, 1992-2004

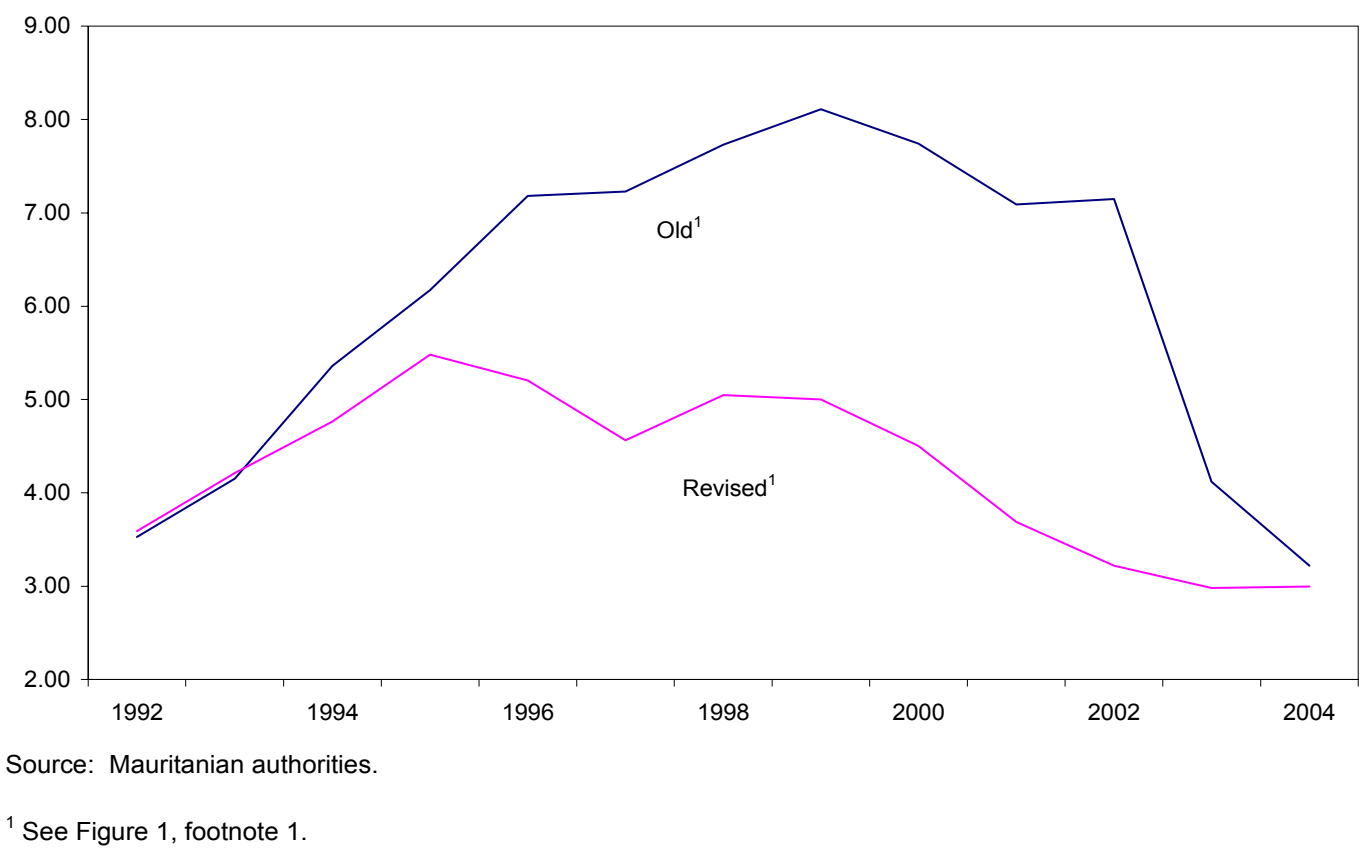

9. The reassessment of past economic performance raised the question of why the misreporting continued and went unnoticed for such a long time. The lack of program ownership and low accountability of government institutions, combined with their deficient domestic oversight, were the main factors perpetuating the misreporting. The apparent consistency of the erroneous data made it difficult to suspect the misreporting, although staff noted several puzzling facts early on. The Fund's safeguards assessment procedures, now effective for all Fund-supported programs, proved instrumental in revealing the misreporting case (Box 1).

\section{Mauritania does not presently qualify as having Longer-Term Program} Engagement (LTPE) under the new definition adopted by the Executive Board. Under the old definition, an ex post assessment of past Fund-supported programs was expected at the end of the 2003 PRGF arrangement (which was cancelled on November 7, 2004), but the data issues have prevented until now its preparation. In any case, evaluating the design and monitoring of past PRGF-supported programs would have limited relevance as these programs were fundamentally distorted by the previous authorities' long-lasting provision of inaccurate information to the Fund. 


\section{Box 1. Mauritania: Causes, Consequences, and Lessons of a Prolonged Misreporting}

Starting as early as with the 1992-94 ESAF-supported program, the authorities provided inaccurate, albeit consistent, data to Fund staff. Revised data indicate that net bank financing of the government and monetary aggregates were underreported and foreign reserves were overreported in a coherent manner, so that program quantitative targets appeared met. The need for continued support from the Fund and the lack of political changeover and program ownership perpetuated the misreporting, hence data inaccuracies accumulated in reports to the Fund.

Until the initiation of the safeguards assessment (SA) procedures, staff did not suspect the misreporting. Over the period, staff noted several puzzling facts, such as large swings in the income velocity of broad money or persistent downward pressures on the exchange rate in spite of the reported comfortable level of official reserves. On several occasions, staff also expressed concerns over the quality of data, in particular consumer price indices, national accounts, and balance of payments statistics. Staff however blamed this on the limited capacity of Mauritania's statistical system and provided assistance and recommendations for data accuracy improvements. Following a review of fiscal transparency in 2002, staff also recommended that top priority should be placed on addressing chronic weaknesses in fiscal accounting and transparency, emphasizing the need for providing the public with more complete and timely fiscal information, and strengthening the mechanisms of external and internal audit (Mauritania-Report on the Observance of Standards and Codes-Fiscal Transparency Module; Country Report 02/268).

The 2004 onsite SA mission was instrumental in leading the authorities to admit, in two steps, that data needed to be revised. The January 2004 SA mission found that only 15 percent of the BCM foreign exchange reserves stated in its 2002 accounts could be reliably confirmed by the external auditor. In September 2004, the new economic team released revised data for 2003 and the first half of 2004 (which led the staff to conclude that the 2003 PRGF-supported program was irremediably off track), but maintained that data for periods prior to 2003 were correct. The transition government's desire to reestablish data transparency and cooperation with the Fund led to the data being revised over the entire 1992-2004 period.

The authorities acknowledge that the misreporting had a heavy cost on the country. The communication of erroneous data for the 1992-2004 period biased past staff assessments and led to inadequate policy recommendations and program designs, including on foreign exchange market issues. In retrospect, fiscal and monetary tightening, not currency depreciation, might have been the main policy instrument to restore confidence in the ouguiya and ensure a durable improvement in the functioning of the foreign exchange market. In fact, these policies were progressively implemented from mid-2004 and contributed to the virtual disappearance of the parallel market premium in late 2005.

The lessons that can be drawn from this misreporting case would be incorporated in the design of a possible Fund-supported program, following satisfactory implementation of the current SMP. Such a program would be based on data that derive from audited central bank's accounts; these audits and the external audit procedures would be evaluated as part of the SA process. Additional SA recommendations may be incorporated in program conditionality. Program ownership, further steps toward fiscal and monetary transparency and good governance, and strengthened domestic oversight and accountability of government institutions will also be critical in preventing the recurrence of misreporting. 


\section{RECENT DEVELOPMENTS AND SHORT-TERM OUTLOOK}

\section{After years of loose macroeconomic policies, the return to sound} macro-management from mid-2004 started to produce encouraging results in late 2005. The BCM tightened monetary policy from mid-2004, but a commensurate tightening of the fiscal stance followed only a year later. Inflation subsided in the last quarter of 2005, when the transition authorities ended extra-budgetary spending and started to improve public finance management (PFM), ultimately containing the deficit (including grants) below 7 percent of GDP (Table 1). Although construction and other sectors heavily dependent on public spending suffered from a temporary slowdown, the run-up to oil production helped maintain the growth momentum at 51/2 percent in 2005. Meanwhile, improved coherence in the policy mix, lower inflation, and the imminent start of oil production strengthened confidence in the ouguiya and reduced the parallel foreign exchange market premium to single-digit levels in the last quarter of 2005 (Figure 3).

\section{The beginning of oil production in 2006 has boosted growth prospects and the} credibility of the authorities' economic stabilization program. Oil production, which started in February 2006 and reached an average of 54,000 barrels per day in March-May 2006, is expected to boost 2006 nominal GDP by nearly 50 percent, with real GDP increasing by 19 percent. Real non-oil GDP is projected to increase by about $6 \frac{1}{2}$ percent in 2006, reflecting the beginning of copper and gold mining and large foreign-financed investments in infrastructure. Outside these sectors, growth prospects remain vulnerable to capacity constraints in the (state-owned) iron ore mining and electricity companies, and soaring fuel prices, which are particularly burdensome for the domestic fishing industry. Based on the January-April 2006 performance, ${ }^{6}$ the authorities' ambitious disinflation target for 2006 appears attainable, provided the present monetary policy stance is maintained. The 20 percent increase in the civil service wage bill was partly a catch-up with the 2005 minimum-wage increase and reportedly has not passed through to the private sector. With the ouguiya de facto pegged to the U.S. dollar, the recent rise of the Euro has reversed much of the significant appreciation of the real effective exchange rate (REER) during 2005, and the fluctuations in the foreign exchange market parallel market premium narrowed to a range of 0.5-3.0 percent over the official exchange rate.

13. The expected oil revenues and the maintenance of fiscal discipline should enable a substantial fiscal consolidation in 2006. Fiscal performance in the first quarter of 2006 was fully satisfactory. By maintaining recurrent spending well within the SMP quarterly limits (while executing poverty-reducing spending in line with annual allocations), the

\footnotetext{
${ }^{6}$ Prices increased by a cumulative 3.2 percent, in part reflecting two rounds of increases to the regulated domestic petroleum product prices, on average by about $9 \frac{1}{2}$ percent on December 30,2005 and 4 percent on February 28, 2006. Another petroleum price increase of about 131/2 percent took place in early May.
} 
Figure 3. Mauritania: Monetary Developments and Exchange Rate Indices
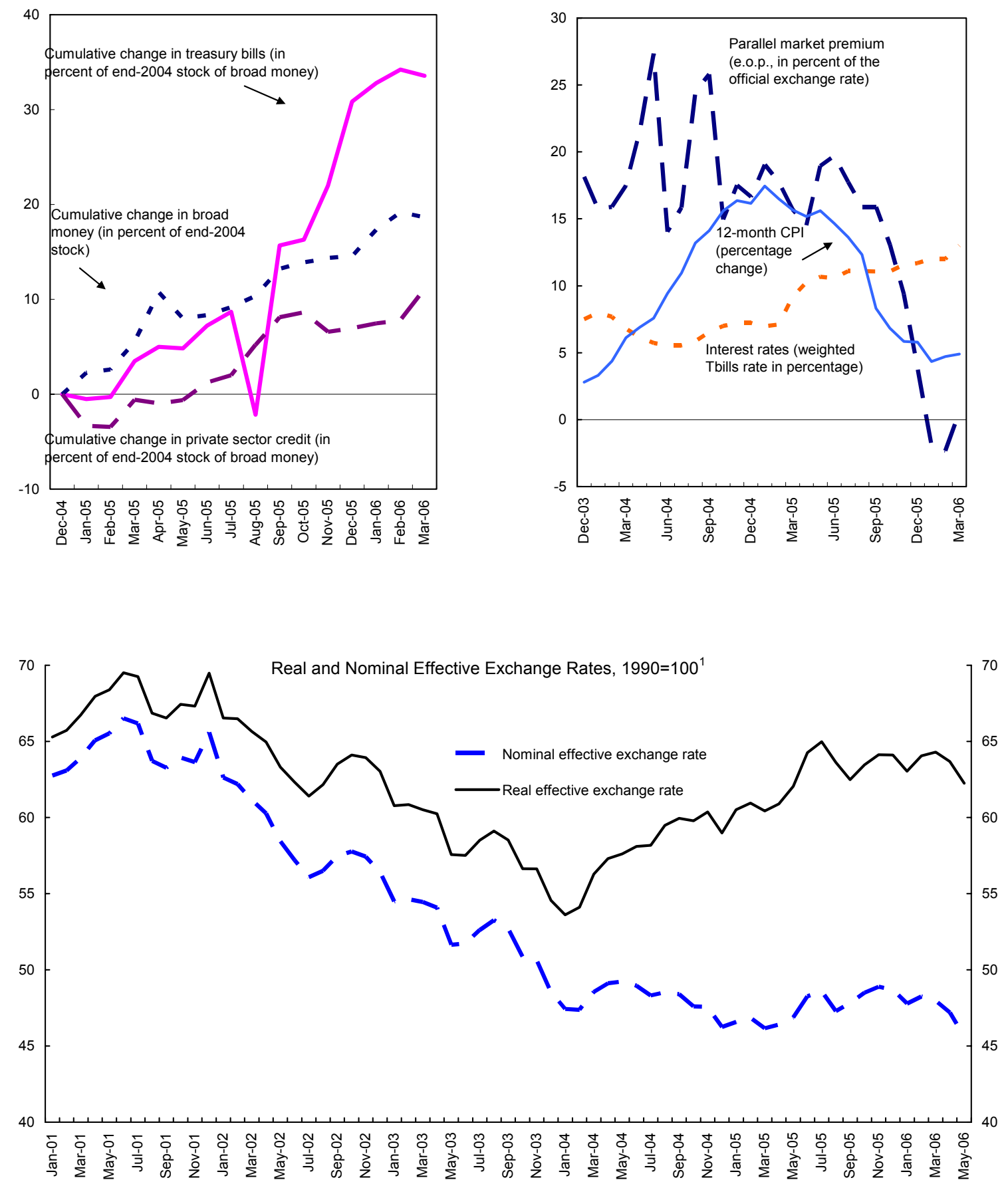

Source: Mauritanian authorities; and Fund staff estimates.

${ }^{1}$ May 2006: staff estimates. 
authorities took advantage of good revenue performance to reduce the treasury float. On current projections, despite the expected revenue loss from fishing, the overall fiscal surplus could exceed 10 percent of non-oil GDP in 2006, much of which is to be used for the reduction of domestic government debt, including payment arrears (Table 2). In addition, the 2006 budget has provided for a substantial increase in social spending (from 6.9 percent of GDP in 2005 to 8.1 percent of non-oil GDP in 2006) and has eliminated all under-budgeting of allocations for embassies, pensions, and government consumption of public services. ${ }^{7}$

14. Efforts to improve public expenditure management continued on a wide front in early 2006, including preparations for the sound management of oil revenues. The 2005 budget execution period was closed (for the first time) within two months from year-end, posting significantly reduced payment arrears. Treasury figures are now reconciled with the $\mathrm{BCM}$ on a continuous basis and are presented in monthly budget execution reports. The adoption of a functional classification enables the improved tracking of budget execution and allows for the identification of poverty reducing expenditure. The Hydrocarbon Revenue Fund (FNRH) is now operational. ${ }^{8}$ On May 10, 2006, the council of ministers adopted a convention that details the delegation of administrative powers for the FNRH from the Ministry of Finance to the BCM.

15. Important tax reforms were also pursued. These included a reform of taxation on fisheries, reorganization of the Large Taxpayers Unit (including the creation of a division dealing with the taxation of the nascent hydrocarbon sector), introduction of the single tax identification number, strengthening of risk management (anti-fraud) procedures by customs, and the extension of customs control over oil exports.

\section{The authorities' decision to end central bank financing of the budget deficit} slowed broad money growth and tightened liquidity conditions in 2005 and in the first quarter of 2006. With the government forced to tap the banking system for its financing needs, liquidity conditions became progressively tighter during 2005. Despite the favorable Treasury situation in the first quarter of 2006, the increase in T-bill rates (now at about 13 percent) at recent auctions suggests that liquidity conditions still remain tight.

Concomitant with a prudent monetary policy stance, the expansion of credit to the economy was also relatively modest (Table 3 ).

17. Mauritania's external position has started to improve on account of favorable terms of trade and the tightened policy stance, but foreign reserves are expected to

\footnotetext{
${ }^{7}$ For a broader discussion of the 2006 budget, see Country Report $06 / 255$.

${ }^{8}$ For a full description of the oil reporting and management framework see Box 1 in Country Report 06/255. Latest developments are characterized in attachment I.
} 
remain low until mid-2006. High world market prices boosted the proceeds of the national iron ore company, while fish exports inched up (Table 4). Combined with the moderate growth of non-fuel imports (excluding foreign direct investment (FDI) -related flows), these positive trends helped improve the underlying external current account balance, despite the sharply increased bill for imported petroleum products. Continued high FDI inflows covered equipment imports by the emerging oil and mining industries. As of end-March 2006, official reserves stood at 0.6 months of import cover (nearly three times the end-March 2005 level).

\section{Starting in the second half of 2006, Mauritania's external position is set to} strengthen considerably with the arrival of oil export proceeds and higher export commodity prices. Based on current projections for oil production, Mauritania's exports will more than triple in 2006 relative to 2005 . Iron ore exports will benefit from a further rise in international prices. The revenue outlook for Mauritania's fisheries sector is more uncertain, depending on when sales of commercial licenses and a higher catch by Mauritania's national fleet will replace the lost revenue from the EU agreement, which will expire on July 31,2006 . The external current account is projected to post a surplus of $3 \frac{1}{2}$ percent of GDP in 2006, despite the surging cost of imported fuel. Net capital inflows will decrease from their high 2005 level, reflecting the amortization of oil-related investments, the anticipated clearance of private external arrears (estimated at US\$67 million at end-March 2006), and commercial banks' strengthening of their foreign exchange positions throughout the year. Official reserves would grow substantially and reach 1.4 months of imports by yearend.

\section{Policy Discussions}

19. Discussions focused on the appropriateness of current macroeconomic policies and implementation of key reforms (notably related to the SMP and MDRI remedial actions, and preparations for the liberalization of the foreign exchange market). Staff, together with the World Bank staff, held discussions with the authorities on the medium-term outlook and policies, based on the first drafts of the Poverty Reduction Strategy Paper (PRSP) and the Medium-Term Budget Framework (MTBF).

\section{A. SMP and MDRI Remedial Actions}

20. The SMP remains firmly on track. Fiscal and monetary aggregates were well within the program targets for end-March (Table 5). All structural indicators have also been observed (Table 6). All other actions that were envisaged in the memorandum of economic and financial policies (MEFP) for the first four months of 2006 have been implemented, including the actions needed to ensure transparent and efficient management of oil revenue and to improve public expenditure management and reporting.

21. Mauritania has implemented all the remedial actions that were required for MDRI qualification (Table 7). The authorities solved the data issues; macroeconomic policies have been satisfactory since October 2005; and all the remedial actions in the areas 
of budget formulation, execution, and reporting have been implemented. In a broad consultative process, the authorities also substantially advanced the preparation of the new poverty reduction strategy $(\$ 34)$. The information available to staff indicates that Mauritania is current on its obligations to the Fund, the World Bank and the African Development Bank.

\section{B. Policies for the Remainder of 2006}

\section{Fiscal Policy}

\section{The authorities are determined to achieve the original fiscal targets for 2006.}

Government revenue prospects have substantially improved since the beginning of the year, but some revenue uncertainties remain. A US\$100 million bonus that the Woodside-led oil consortium agreed to pay upon the signing of the revised production-sharing contract and higher expected tax payments by oil companies are likely to boost oil revenue substantially above the original 2006 projections. ${ }^{9}$ Lower revenues could not be excluded outside the oil sector, unless alternative sources are secured (as envisaged in the original budget projection) to cover at least $2 \frac{1}{2}$ percent of GDP representing half the revenue loss due to the non-renewal of the EU fisheries agreement. The revenue neutrality of the recent changes in the taxation of imports and the domestic fishing industry remains also to be confirmed. ${ }^{10}$ With the forthcoming Fund (TA) on trade taxation and customs administration, the authorities will prepare a comprehensive package of reforms in these areas to be included in the 2007 budget.

\section{To consolidate macroeconomic stability, the authorities intend to adhere to the} original budget spending limits for 2006. The authorities plan to pass a supplementary budget ordinance to enable a transfer of up to US\$150 million from the FNRH to the Treasury account at the BCM, in order to reduce domestic government debt and strengthen official reserves. Within these limits, the authorities are preparing rehabilitation plans for two parastatals, Sonimex (whose interventions have aimed to regulate domestic markets for sensitive staple goods) and Air Mauritanie, a partially privatized domestic carrier. The authorities considered the survival of both companies in the public interest, although their viability is questionable under present local market conditions. The staff agreed that the future PRGF-supported program should address these and a few other public enterprise -related issues to protect the budget against potential drains.

\footnotetext{
${ }^{9}$ Assuming that the pace of oil extraction can be maintained as projected. Tax revenue projections have been reassessed on the basis of declarations filed by oil operators in April.

${ }^{10}$ Main changes to import taxation included applying transaction prices (rather than artificially low reference prices) for import valuation while reducing nominal tariff rates and eliminating excises on sugar, tea, and tobacco. The reform of fishing taxation, broadly endorsed by Fund tax experts, consisted in adopting a system of access rights with fixed (per boat) and variable (per catch, species-dependent) components with a view to improving the management of fishing resources.
} 
24. The authorities aim to achieve further progress in expenditure management. The

Treasury intends to maintain the payment float significantly below the UM 10 billion ceiling projected for 2006 (the equivalent of a one-month average payment delay) to strengthen confidence and foster competition in the public procurement system. Expenditure controls will continue to be strengthened, both ex ante (with the planned computerization of the spending authorization circuit) and ex post (with the ongoing development of onsite inspections by the State General Inspectorate).

\section{Monetary and Exchange Rate Policy}

25. The $\mathrm{BCM}$ is maintaining a strict monetary policy with no central bank financing of the budget and interest rates geared toward building up official reserves while keeping inflation under control. Bank liquidity will remain tight through mid-year until proceeds from the additional oil revenue will allow the Treasury to reduce the volumes of T-bill auctions. The strengthened external position of the BCM will enable the clearance of private external arrears, which in turn is expected to entail a significant drawdown of bank deposits. As a result, broad money growth for 2006 is now projected at below 16 percent. Although the implied room for credit growth will be relatively modest throughout the year, reduction in government arrears is expected to bring the growth rate of financing available to the economy to 16.9 percent.

\section{The monetary authorities acknowledged the need to diversify their policy} instruments. At present, reserve requirements are the only liquidity management instrument the BCM has at its disposal. The BCM is aware of the challenges arising in this respect once oil surpluses eliminate the primary rationale for Treasury's borrowing from the banking system. In this context, building on recent Fund TA, the authorities are considering the pros and cons of several instruments (including issuing central bank bills) that could be used to afford the appropriate liquidity management flexibility, in coordination with the Treasury and in step with the development of an interbank market and a secondary market for T-bills.

27. There is no apparent need to adjust the official exchange rate against the U.S. dollar before the planned move toward a more flexible exchange rate policy, together with the introduction of foreign exchange auctions, possibly in the second half of 2006. The foreign exchange parallel market premium remains low and the depreciation of the ouguiya against the Euro significantly reversed the 2005 upward REER movement. The authorities keenly discussed the specifics of the new exchange rate regime and intervention policy. Although they support the move toward market-based exchange rates, they foresee the central bank having a role in limiting day-to-day fluctuations while targeting a broadly stable REER to preserve the competitiveness of the non-oil sectors. Staff argued that a certain degree of REER appreciation might be unavoidable and that competitiveness should be dealt within a broader policy framework. 
28. The authorities outlined the conditions and the timetable for the successful introduction of foreign exchange auctions. The new system will ensure free access to foreign exchange for current international transactions. A key step will be the elimination by October 2006 of foreign exchange rationing, an exchange restriction which contravenes Mauritania's obligations under Article VIII, Section 2 (a), of the Fund's Articles of Agreement. Given the present difficult balance of payments situation, the authorities requested the Fund to approve this restriction on the grounds that it is strictly temporary and is applied on a nondiscriminatory basis. Furthermore, the authorities established a timetable for the launching of foreign exchange auctions, including the required preliminary and accompanying measures such as the elimination of the existing partial (60 percent) surrender requirement for fish exports. They intend to introduce the new system before end-2006, provided that official reserves reach at least two months of import cover (for imports that are not financed by FDI or foreign assistance). The preparations of necessary regulations, including decrees for the establishment of a foreign exchange market and for the monitoring of commercial banks' net foreign open positions are under way.

\section{External Sector Policies}

\section{The authorities reiterated their commitment to seek final agreements with} bilateral creditors (Algeria, Iraq, Libya, and the United Arab Emirates) that have not yet provided irrevocable HIPC relief. A related important issue is the status of passive debt (debt that was excluded from HIPC relief calculations at the decision point) to Kuwait and Libya. ${ }^{11}$ The authorities pointed out their renewed - yet thus far unsuccessful — efforts to reach an agreement on a treatment comparable to the one granted on Mauritania's Paris Club debt. $^{12}$

\section{Regarding trade policies, the authorities are pursuing regional integration and} trade facilitation efforts with neighboring countries. Mauritania is associated in the ongoing negotiations for an Economic Partnership Agreement between ECOWAS countries and the European Union, which could lead to a free trade agreement with both of them, possibly as early as end-2007, and greater financial support from the EU for investments in infrastructure and industrial development. The staff encouraged the authorities to carefully assess the implications of the partnership with the EU and urged them to complement the preferential liberalization with MFN-based tariff reduction to minimize trade diversion. The

\footnotetext{
${ }^{11}$ In the absence of debt treatment (contrary to the agreements that Mauritania obtained on its debt vis-à-vis Paris Club creditors), the authorities estimate that Kuwait's "passive debt" claims on Mauritania have snowballed from US\$49 million in 1981 to US\$904 million (including late fees and interests) in 2005, while Libya's interest-free "passive debt" claims stand at US\$11 million.

${ }^{12}$ An agreement would also help resolve accounting issues with regard to the BCM's liabilities toward Kuwait and Libya, which the authorities intend to rectify by end-2006.
} 
Mauritanian authorities have also decided to join the Maghreb countries' trade facilitation initiative.

\section{Financial Sector Reforms}

31. Discussions on the preliminary conclusions of the FSAP mission focused on ways to improve financial sector stability, promote competition in the banking sector, and improve access to banking services (Box 2). The authorities undertook to implement promptly the recommendations regarding banking supervision, including on the production of more credible financial statements, a more rigorous implementation of prudential regulations, and measures aimed at ensuring good governance.

32. The mission discussed with the authorities the preparations of the financial system against a possible avian flu pandemic. Mauritania's coastal wetlands are a major nesting place for a large variety of migratory birds, which makes it particularly vulnerable to the avian flu. In the context of a national plan to fight a possible avian flu pandemic, the $\mathrm{BCM}$ is preparing a set of measures to limit disruptions to the financial system, including through awareness campaigns for the staff of commercial banks.

33. The authorities have taken steps toward establishing a fully fledged Anti-Money Laundering and Combating the Financing of Terrorism (AML/CFT) framework. Mauritania adopted the relevant legislation in mid-2005 and joined the Middle East \& North Africa Financial Action Task Force in early 2006. The setting up of the national AML/CFT committee and the financial intelligence unit at the BCM is under way.

\section{E. Poverty Reduction Strategy and the Medium-Term Framework}

\section{The authorities prepared drafts of the second poverty reduction strategy paper} (PRSP) and the medium-term budgetary framework (MTBF). The new PRSP covers the period 2006-10 and is embedded in a very ambitious long-term vision that reflects Mauritania's dramatically improved resource prospects, (including possible MDRI debt relief) enabling a significant increase in social spending. ${ }^{13}$ Drawing important lessons from the shortcomings of the previous PRSP, the new PRSP recognizes that poverty in Mauritania ought to be approached as a predominantly rural phenomenon. As a result, improved targeting of the pro-poor expenditure and intervention programs will lead to a strategy for the development of regions and local communities. However, additional work is needed to: (a) undertake a deeper analysis of the link between economic growth, existing or proposed policies and poverty reduction; (b) use existing costing exercises with a view to

\footnotetext{
${ }^{13}$ One long-term objective is to reduce the poverty headcount from nearly 47 percent in 2004 to 35 percent in 2010 and 15 percent in 2015; significantly beyond the Millennium Development Goals (Table 8). The MTBF assumes that the share of expenditure on education, health, and rural development will increase from $31 \frac{1}{2}$ percent to nearly 35 percent of all expenditure between 2007 and 2009.
} 


\section{Box 2. Mauritania: Preliminary Findings of the FSAP Mission}

A Bank/Fund staff mission visited Nouakchott during February 19-March 3, 2006 to complete the FSAP that had been initiated in February 2005. A successful assessment was made possible by the new authorities' decision to provide the needed financial sector data which had been previously withheld. The mission assessed the performance of the financial sector, reviewed its regulatory framework and judicial environment, and identified the range of financial services available. The FSSA is expected to be discussed at the Board this Fall.

The FSAP mission found that financial services in Mauritania are underdeveloped, with the banking system still accounting for an overwhelming share of the financial sector. While banks hold 88 percent of the financial sector's total assets, bank loans and deposits represent less than 20 percent of GDP. Most banks have close ties with local conglomerates, and channel the savings of the public in their direction. For corporations with no direct links to a bank and for the public at large, especially poorer households and clients in rural areas, banks' services are hardly accessible, limited, costly, and obsolete.

Banks' financial conditions as reported seem fair, with reasonable levels of equity and profitability. On the whole, this does not raise immediate stability concerns. The main issues affecting banks' financial stability are a substantial shortage of provisions for nonperforming loans (2.5 percent of GDP), some questions about their reported profitability, and the general opacity of their accounts. ${ }^{1}$ Deducting in full the missing provisions from the banks' net worth would lower their average equity-to-assets ratio only from 20 percent to 12.2 percent — still well above the 8 percent prudential floor.

Stress testing has identified two main vulnerabilities. Credit risk, including risk concentration, is Mauritanian banks' main vulnerability. Banks are also highly sensitive to the level of interest rates, with lower rates having a large negative impact on their financial performance because interest income represents a large part of their total income while interest expenses are quite low and inelastic (most deposits are short term with no or very low remuneration).

The FSAP mission found that banking supervision has been strengthened but the regulatory framework still lags significantly behind international standards. In 2005, the BCM improved onsite inspections of banks, and better enforced provisioning requirements. However, inspection reports, uneven in quality, do not analyze banks' profitability and are not sufficiently documented. Mauritania fully complies with only three of the Basel Core Principles, and largely complies with another eight.

Non-bank financial services are at an early stage of development. Microfinance institutions are numerous (63 licenses) but hold only one percent of financial sector assets and most have not achieved self sufficiency. The prudential framework requires a comprehensive overhaul and central bank supervision in this area needs strengthening. The penetration of the insurance sector is particularly low and, although its regulatory framework is by and large in line with international norms, supervision is ineffective for lack of adequate resources.

\footnotetext{
${ }^{1}$ At present, the BCM is actively monitoring the cases of a small bank in difficulty and of a larger undercapitalized bank.
} 
aligning the MTBF and the budget with the priority programs identified in the PRSP; and (c) build a consensus on priorities that can survive the forthcoming election cycle.

35. The discussion focused on the use of oil revenue to achieve Mauritania's growth and poverty reduction objectives, while preserving macroeconomic stability and avoiding undue real exchange rate appreciation. ${ }^{14}$ With a view to laying the groundwork for future PRGF discussions, the authorities agreed with staff on a baseline scenario founded on a prudent assessment of oil revenue prospects, featuring a nonoil primary deficit increasing by about $13 / 4$ percent of nonoil GDP per year over the next three years, and gradually bringing capital expenditures to about 12 percent of nonoil GDP (Table 9). The authorities acknowledged the need to accumulate savings in the oil account, while keeping current government expenditures in pace with nonoil GDP growth to avoid hard budgetary choices in case of a downturn in the world oil market. They established a working group in charge of preparing a rules-based framework for the use of oil revenues, which will be incorporated in a future hydrocarbon law.

36. The authorities intend to remain vigilant on competitiveness issues, especially in view of Mauritania's still narrow export base and the risk of Dutch disease. They are determined to limit future real exchange rate appreciation that might arise from the incipient oil boom and agreed with staff on the central role that savings in the FNRH should play in this respect. Staff also argued that competitiveness should be taken into account in the ongoing wage policy discussions. Excessive upward wage pressure would undermine the development of agriculture and fish processing industries, which may be the primary vehicles for diversifying Mauritania's production and export base. The authorities concurred with this view but also highlighted the need to address the problem of weak productivity, including through ambitious public programs geared toward physical and human capital accumulation.

\section{Against the backdrop of the rapidly improving external debt situation, the} authorities are planning to develop a medium-term debt management strategy. Strong economic growth will bring the ratio of nominal public external debt to GDP below 70 percent in 2006. Qualification for MDRI relief would further reduce the nominal debt stock by about 39 percent (Table 10), ${ }^{15}$ implying a much more benign outlook for debt sustainability. Going forward, the principal challenge consists in avoiding a resurgence of external liabilities. The authorities acknowledged the need to pursue prudent policies with respect to the contracting of new loans. However, they also emphasized Mauritania's substantial needs in terms of public infrastructure investment; several ongoing

\footnotetext{
${ }^{14}$ These issues were covered extensively in the 2005 Selected Issues (Country Report 06/248, Chapter I: "Managing Oil Wealth".

${ }^{15}$ The expected amount of MDRI debt write-off also includes liabilities that are already subject to flow relief under the HIPC initiative. Mauritania's external debt situation will be examined in greater detail in a joint BankFund debt sustainability analysis, which is scheduled for the Fall of 2006.
} 
foreign-financed projects, such as the new Nouakchott airport, were already initiated by the previous government. The authorities have recently created a national public debt committee to prepare (with Fund TA) a comprehensive debt management strategy.

38. The authorities agreed with staff on the main reform areas to be covered in the medium-term economic program that could be supported by the PRGF. These would include oil revenue management and external debt management strategies, further strengthening of public finance management and wage policy, public enterprise restructuring, and financial sector reforms.

\section{STAFF APPRAISAL}

39. In the past ten months, the Mauritanian transition authorities have implemented an impressive policy shift toward transparency and good governance. The resolution of the data issues that had plagued Mauritania's relations with the Fund since 2004 also opened the road to Mauritania's qualification for the MDRI and initiated a track record for the use of Fund resources under an SMP covering the first half of 2006. The program rightly focuses on the consolidation of macroeconomic stability and the strengthening of the still fragile external position through the prudent budgetary use of the newly acquired oil revenues and no central bank budget financing. The authorities should be commended for the strict implementation of their staff-monitored program during the first four months of 2006.

\section{Staff considers that Mauritania has met all the criteria for MDRI qualification,} including the resolution of the data issues, six months of satisfactory macroeconomic performance (October 2005-March 2006), and implementation of the PFM remedial actions. Broad consultations are under way on a new poverty reduction strategy for 2006-10. The anticipated debt relief should lead to higher poverty reducing outlays in the 2007 budget and in the medium term. The newly-adopted functional classification of expenditure will enhance their targeting and tracking.

\section{Mauritania's swift implementation of several key public finance management} reforms is encouraging, but progress needs to continue. The measures implemented by the new authorities will improve checks and balances on public expenditures. The newly instituted State General Inspectorate's "reality checks" on public spending, going beyond controlling the regularity of spending procedures, are also welcome. The 2007 budget will benefit from the early integration of the MTBF exercise in the budget preparation cycle, but further work will be needed to improve its presentation. A strong drive will also be required for the successful decentralization and computerization of the public expenditure chain, both within the Ministry of Finance and with line ministries.

\section{The decision to adhere to the original budgetary ceilings on government} spending, despite significantly higher-than-budgeted oil revenue in 2006, will allow further reduction of domestic debt. It will also enable the BCM to rebuild its foreign reserves and eliminate the remaining exchange restriction in parallel with a reduction of 
private sector external arrears; all three elements being of critical importance for the central bank to prepare for a decisive and credible foreign exchange market reform. The next budget should focus on reforms of international trade taxation and civil servants' remunerations based on a thorough review of the civil service functional grid. The selection of public investment projects should be geared toward addressing critical growth bottlenecks and the new PRSP priorities. Ailing parastatals' further drain on public resources should be stopped.

\section{The establishment of transparent mechanisms to collect and channel}

government oil revenues needs to be pursued. Staff welcomes progress made to ensure proper and timely reporting, auditing, and publication of oil production, sales and revenue data, and the operational start of the offshore hydrocarbon revenue fund. Efforts should continue to put in place rigorous control and audit mechanisms (in particular, to strengthen the finance ministry's oversight over oil revenue collection, and to proceed with the appointment of an auditor of international reputation) and, with Fund technical assistance, to set up an institutional decision-making process for the efficient management and use of these revenues.

\section{The recent sizable interest rate increases have strengthened the BCM's} credibility in pursuing price stability but careful monitoring of international and domestic price pressures is still required to control the risks to the 2006 disinflation objective. With the issuance of T-bills expected to decline, the BCM will need to develop alternative instruments for more active liquidity management. In a not too distant future, a more flexible exchange rate policy would help contain inflation pressures that could originate from increased domestic absorption and capital inflows. However, the central bank cannot by itself control REER appreciation. The well-regulated spending of government oil revenue (through the oil fund mechanism) and the channeling of this spending into priority physical and human capital investment projects should be the main safeguards of non-oil sectors' competitiveness. Well-designed trade liberalization should also help in this endeavor.

\section{Staff welcomes the BCM's decision to eliminate the present foreign exchange} rationing system by October 2006, to phase out the partial surrender requirements on fish export proceeds, and to help eliminate private external arrears. These steps will inspire confidence in the ouguiya and create a sound basis for the successful introduction of foreign exchange auctions. Staff supports the authorities' request for Board approval of the balance-of-payments-related temporary and nondiscriminatory foreign exchange rationing, which constitutes an exchange restriction under Article VIII, Section 2 (a).

\section{Successful SMP implementation through end-June 2006 will be needed to} establish a good track record toward a possible PRGF-supported program. While the draft PRSP is a good basis for PRGF discussions, the authorities need to identify in the coming months the priority actions needed to unleash Mauritania's growth potential and help reach its ambitious poverty reduction goals. Given the pluralism of the political scene that is likely to emerge in the aftermath of the general elections, a broad political consensus may be 
crucial to support these actions. In the staff's view, a promising and sustainable poverty reduction strategy should focus on the market-based development of labor-intensive industries based on primary goods for which Mauritania has a comparative advantage (including fish, agriculture, and livestock). In this context, a PRGF-supported program should focus on a growth-enhancing framework of sound macroeconomic, trade, financial, and good governance policies. Improved data collection and analysis should also remain key priorities.

47. It is proposed that the next Article IV consultation take place on the standard 12-month cycle. 
Table 1. Mauritania: Selected Economic and Financial Indicators, 2001-06

\begin{tabular}{|c|c|c|c|c|c|c|}
\hline & 2001 & 2002 & 2003 & 2004 & \multirow{2}{*}{$\frac{2005}{\text { Prel. }}$} & \multirow{2}{*}{$\frac{2006}{\text { Proj. }}$} \\
\hline & \multicolumn{4}{|c|}{ Revised } & & \\
\hline & \multicolumn{6}{|c|}{ (Percentage changes; unless otherwise indicated) } \\
\hline \multicolumn{7}{|l|}{ National income and prices } \\
\hline GDP at constant prices $1 /$ & 2.9 & 1.1 & 5.6 & 5.2 & 5.4 & 19.4 \\
\hline Non-oil GDP at constant prices & 2.9 & 1.1 & 5.6 & 5.2 & 5.4 & 6.8 \\
\hline GDP deflator $1 /$ & 7.9 & 7.8 & 2.5 & 11.5 & 18.9 & 44.3 \\
\hline Non-oil GDP deflator & 7.9 & 7.8 & 2.5 & 11.5 & 18.9 & 8.7 \\
\hline Consumer price index (period average) & 7.7 & 5.4 & 5.3 & 10.4 & 12.1 & 6.5 \\
\hline Consumer price index (end of period) & 4.1 & 8.4 & 2.9 & 16.1 & 5.8 & 8.1 \\
\hline \multicolumn{7}{|l|}{ External sector } \\
\hline Exports of goods, f.o.b. (percentage change in U.S. dollars) & 0.2 & -6.6 & -4.1 & 38.1 & 37.4 & 213.2 \\
\hline Of which: non-oil & 0.2 & -6.6 & -4.1 & 38.1 & 37.4 & 27.9 \\
\hline Imports of goods, f.o.b. (percentage change in U.S. dollars) & 2.4 & -7.3 & 25.7 & 70.3 & 50.3 & -12.9 \\
\hline Imports of goods, f.o.b. (percentage change in U.S. dollars) 2/ & -7.0 & -7.6 & 22.1 & 33.7 & 14.7 & 17.4 \\
\hline Official transfers (in percent of GDP) & 6.9 & 5.1 & 6.9 & 4.1 & 3.8 & 2.5 \\
\hline Current account balance (in percent of GDP) & -11.7 & 3.0 & -13.6 & -34.6 & -49.9 & 3.5 \\
\hline Current account balance (in percent of GDP) 2/ & -6.7 & 7.6 & -7.1 & -11.9 & -7.8 & -8.9 \\
\hline Overall balance (in percent of GDP) & -7.6 & -2.8 & -9.9 & -7.3 & -3.9 & 4.8 \\
\hline \multicolumn{7}{|l|}{ Official reserves } \\
\hline Gross official reserves (in millions of US\$, end-period) 3/ & 40 & 74 & 32 & 39 & 70 & 152 \\
\hline In months of following year's imports of goods and services 2/ & 0.9 & 1.4 & 0.4 & 0.5 & 0.7 & 1.4 \\
\hline \multicolumn{7}{|l|}{ Money and credit } \\
\hline Money and quasi-money & 34.3 & 23.8 & 25.5 & 13.5 & 14.6 & 15.8 \\
\hline \multirow[t]{2}{*}{ Currency in circulation } & 17.6 & 17.7 & 47.5 & -3.4 & 14.8 & 12.8 \\
\hline & \multicolumn{6}{|c|}{ (In percent of non-oil GDP) } \\
\hline \multicolumn{7}{|l|}{ Consolidated government operations } \\
\hline Revenue and grants & 24.7 & 34.8 & 35.4 & 32.9 & 26.4 & 43.0 \\
\hline Revenue and grants (excluding oil) & 24.7 & 34.8 & 35.4 & 32.9 & 26.4 & 26.1 \\
\hline Idem, excluding grants & 20.7 & 30.4 & 30.7 & 29.7 & 24.4 & 23.6 \\
\hline Oil revenue 4/ & $\ldots$ & $\ldots$ & $\ldots$ & $\ldots$ & $\ldots$ & 17.0 \\
\hline Expenditure and net lending & 35.0 & 37.6 & 47.2 & 37.7 & 33.5 & 32.6 \\
\hline Overall balance including grants & -10.3 & -2.9 & -11.8 & -4.8 & -7.0 & 10.5 \\
\hline Overall non-oil balance excluding grants & -14.3 & -7.2 & -16.4 & -8.0 & -9.1 & -8.9 \\
\hline Overall non-oil balance including grants & -10.3 & -2.9 & -11.8 & -4.8 & -7.0 & -6.5 \\
\hline \multicolumn{7}{|l|}{ Memorandum items: } \\
\hline Ouguiya/US\$ exchange rate (end of period) & 264.1 & 268.7 & 265.6 & 256.2 & 268.6 & $\ldots$ \\
\hline Exports, f.o.b. (in millions of U.S. dollars) & 355 & 332 & 318 & 440 & 604 & 1,892 \\
\hline Imports, f.o.b. (in millions of U.S. dollars) 2/ & 415 & 383 & 468 & 625 & 718 & 843 \\
\hline Nominal GDP (in billions of ouguiya) & 287 & 312 & 338 & 397 & 497 & 857 \\
\hline Nominal non-oil GDP (in billions of ouguiya) & $\ldots$ & $\ldots$ & $\ldots$ & $\ldots$ & $\ldots$ & 577 \\
\hline Nominal GDP (in millions of U.S. dollars) & 1,122 & 1,150 & 1,285 & 1,495 & 1,871 & 3,189 \\
\hline Population (in millions) & 2.57 & 2.63 & 2.69 & 2.76 & 2.82 & 2.89 \\
\hline GDP per capita (in U.S. dollars) & 437 & 437 & 477 & 542 & 663 & 1,103 \\
\hline REER (12-month percentage change; end of period) 5 / & 4.5 & -9.3 & -13.4 & 8.1 & 8.7 & 0.3 \\
\hline
\end{tabular}

Sources: Mauritanian authorities; and Fund staff estimates and projections.

1/ The large increase in the GDP deflator in 2006 (and the relatively low increase in real GDP for this year) reflect the authorities' choice of 1998 as the base year for the calculation of national accounts at constant prices. Oil prices were at a low in 1998.

2/ Excluding oil exploration/production and other mining (copper, gold)-related activities.

3/ Excluding oil account.

4/ Including oil signature bonuses.

5/ In 2006: estimates through end-May.

\section{CInternational Monetary Fund. Not for Redistribution}


Table 2. Mauritania: Central Government Operations, 2003-06 1/

(In billions of ouguiya, unless otherwise indicated)

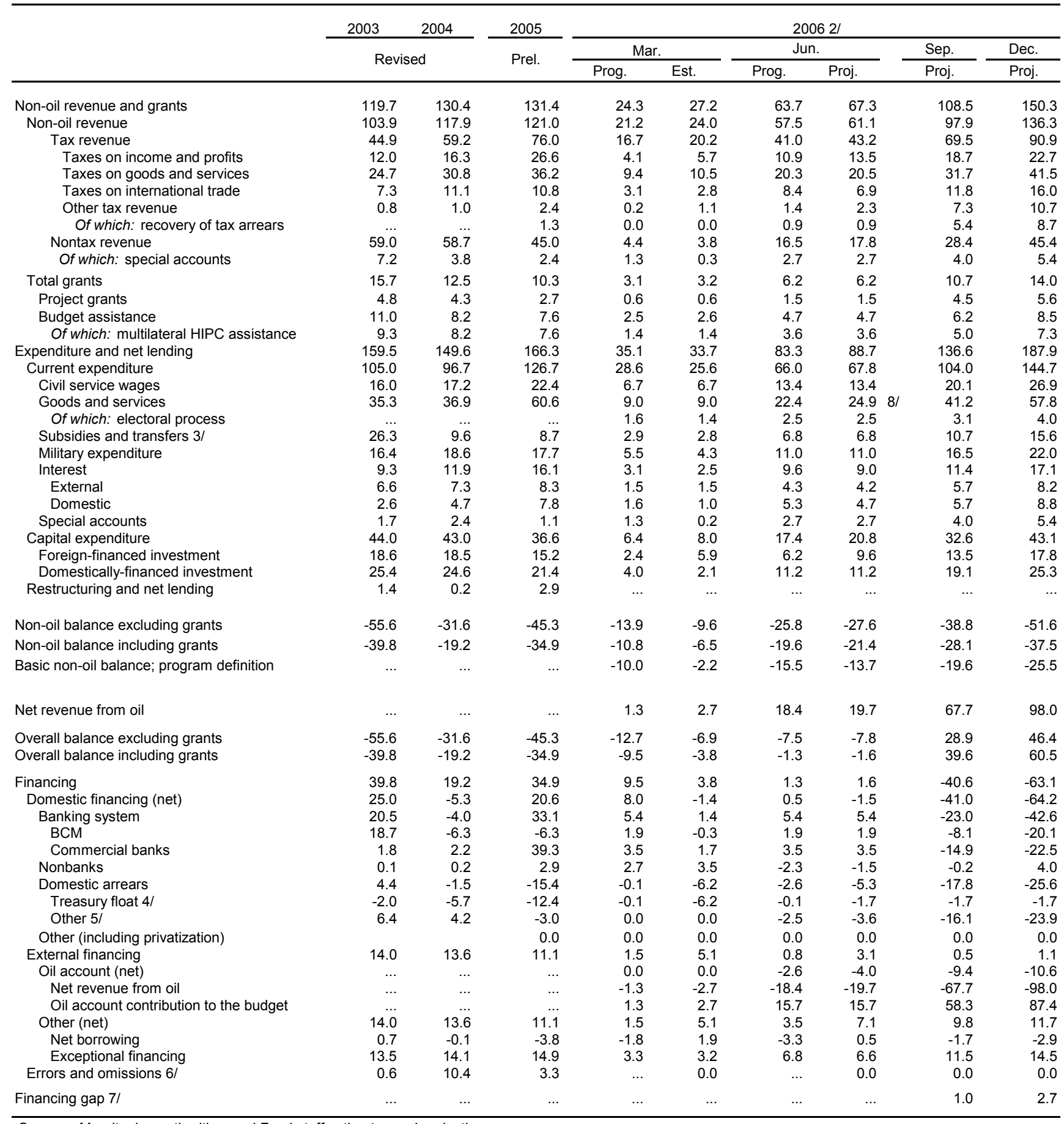

Sources: Mauritanian authorities; and Fund staff estimates and projections.

1/ Cash basis adjusted for extrabudgetary spending until 2004, payment order basis thereafter.

2/ On a cumulative basis.

$3 /$ Including transfers to public entities outside central government.

4/ Net change in outstanding payment orders registered by the Treasury.

5/ Arrears accrued at the budget; related to the expenditure that were executed, but for which payment orders were not issued, and payments were not made.

6/ A significant increase in errors and omissions in 2004 is probably related to arrears on extra-budgetary expenditure.

7/ Expected to be covered by possible MDRI relief.

8/ The upward revision in Q2 reflects a reassessment of spending seasonality to account for annual rent on government-leased property falling due in June. 
Table 2. Mauritania: Central Government Operations, 2003-06 (continued) 1/ (In percent of annual non-oil GDP; unless otherwise indicated)

\begin{tabular}{|c|c|c|c|c|c|c|c|c|c|}
\hline & \multirow[t]{3}{*}{2003} & 2004 & \multirow{3}{*}{$\begin{array}{l}2005 \\
\text { Prel. }\end{array}$} & \multicolumn{6}{|c|}{$20062 /$} \\
\hline & & \multirow{2}{*}{ ised } & & \multicolumn{2}{|c|}{ Mar. } & \multicolumn{2}{|c|}{ Jun. } & \multirow{2}{*}{$\begin{array}{l}\text { Sep. } \\
\text { Proj. }\end{array}$} & \multirow{2}{*}{$\begin{array}{l}\text { Dec. } \\
\text { Proj. }\end{array}$} \\
\hline & & & & Prog. & Est. & Prog. & Proj. & & \\
\hline Non-oil revenue and grants & 35.4 & 32.9 & 26.4 & 4.2 & 4.7 & 11.0 & 11.7 & 18.8 & 26.1 \\
\hline Non-oil revenue & 30.7 & 29.7 & 24.4 & 3.6 & 4.2 & 9.9 & 10.6 & 17.0 & 23.6 \\
\hline Tax revenue & 13.3 & 14.9 & 15.3 & 2.9 & 3.5 & 7.1 & 7.5 & 12.0 & 15.8 \\
\hline Taxes on income and profits & 3.6 & 4.1 & 5.4 & 0.7 & 1.0 & 1.9 & 2.3 & 3.2 & 3.9 \\
\hline Taxes on goods and services & 7.3 & 7.8 & 7.3 & 1.6 & 1.8 & 3.5 & 3.6 & 5.5 & 7.2 \\
\hline Taxes on international trade & 2.2 & 2.8 & 2.2 & 0.5 & 0.5 & 1.4 & 1.2 & 2.0 & 2.8 \\
\hline Other tax revenue & 0.2 & 0.3 & 0.5 & 0.0 & 0.2 & 0.2 & 0.4 & 1.3 & 1.9 \\
\hline Of which: recovery of tax arrears & & & 0.3 & 0.0 & 0.0 & 0.2 & 0.2 & 0.9 & 1.5 \\
\hline Nontax revenue & 17.5 & 14.8 & 9.1 & 0.8 & 0.7 & 2.8 & 3.1 & 4.9 & 7.9 \\
\hline Of which: special accounts & & $\ldots$ & 0.5 & 0.2 & 0.1 & 0.5 & 0.5 & 0.7 & 0.9 \\
\hline Total grants & 4.7 & 3.1 & 2.1 & 0.5 & 0.5 & 1.1 & 1.1 & 1.8 & 2.4 \\
\hline Project grants & $\ldots$ & $\ldots$ & 0.5 & 0.1 & 0.1 & 0.3 & 0.3 & 0.8 & 1.0 \\
\hline Budget assistance & $\ldots$ & $\ldots$ & 1.5 & 0.4 & 0.4 & 0.8 & 0.8 & 1.1 & 1.5 \\
\hline Of which: multilateral HIPC assistance & 1.9 & 1.3 & 1.5 & 0.2 & 0.2 & 0.6 & 0.6 & 0.9 & 1.3 \\
\hline Expenditure and net lending & 47.2 & 37.7 & 33.5 & 6.0 & 5.8 & 14.3 & 15.4 & 23.7 & 32.6 \\
\hline Current expenditure & 31.1 & 24.4 & 25.5 & 4.9 & 4.4 & 11.3 & 11.8 & 18.0 & 25.1 \\
\hline Civil service wages & 4.7 & 4.3 & 4.5 & 1.2 & 1.2 & 2.3 & 2.3 & 3.5 & 4.7 \\
\hline Goods and services & 10.4 & 9.3 & 12.2 & 1.6 & 1.6 & 3.9 & 4.3 & 7.1 & 10.0 \\
\hline Of which: electoral process & & $\ldots$ & $\ldots$ & 0.3 & 0.2 & 0.4 & 0.4 & 0.5 & 0.7 \\
\hline Subsidies and transfers $3 /$ & 7.8 & 2.4 & 1.8 & 0.5 & 0.5 & 1.2 & 1.2 & 1.9 & 2.7 \\
\hline Military expenditure & 4.9 & 4.7 & 3.6 & 0.9 & 0.8 & 1.9 & 1.9 & 2.9 & 3.8 \\
\hline Interest & 2.7 & 3.0 & 3.2 & 0.5 & 0.4 & 1.7 & 1.6 & 2.0 & 3.0 \\
\hline External & 2.0 & 1.8 & 1.7 & 0.3 & 0.3 & 0.7 & 0.7 & 1.0 & 1.4 \\
\hline Domestic & 0.8 & 1.2 & 1.6 & 0.3 & 0.2 & 0.9 & 0.8 & 1.0 & 1.5 \\
\hline Special accounts & 0.5 & 0.6 & 0.2 & 0.2 & 0.0 & 0.5 & 0.5 & 0.7 & 0.9 \\
\hline Capital expenditure & 13.0 & 10.9 & 7.4 & 1.1 & 1.4 & 3.0 & 3.6 & 5.7 & 7.5 \\
\hline Foreign-financed investment & 5.5 & 4.7 & 3.1 & 0.4 & 1.0 & 1.1 & 1.7 & 2.3 & 3.1 \\
\hline Domestically-financed investment & 7.5 & 6.2 & 4.3 & 0.7 & 0.4 & 1.9 & 1.9 & 3.3 & 4.4 \\
\hline Restructuring and net lending & 0.4 & 0.0 & 0.6 & 0.0 & 0.0 & 0.0 & 0.0 & 0.0 & 0.0 \\
\hline Non-oil balance excluding grants & -16.4 & -8.0 & -9.1 & -2.4 & -1.7 & -4.4 & -4.8 & -6.7 & -8.9 \\
\hline Non-oil balance including grants & -11.8 & -4.8 & -7.0 & -1.9 & -1.1 & -3.4 & -3.7 & -4.9 & -6.5 \\
\hline Basic non-oil balance; program definition & $\ldots$ & $\ldots$ & $\ldots$ & -1.7 & -0.4 & -2.7 & -2.4 & -3.4 & -4.4 \\
\hline Net revenue from oil & $\ldots$ & $\ldots$ & $\ldots$ & 0.2 & 0.5 & 3.2 & 3.4 & 11.7 & 17.0 \\
\hline Overall balance excluding grants & -16.4 & -8.0 & -9.1 & -2.2 & -1.2 & -1.3 & -1.4 & 5.0 & 8.0 \\
\hline Overall balance including grants & -11.8 & -4.8 & -7.0 & -1.6 & -0.7 & -0.2 & -0.3 & 6.9 & 10.5 \\
\hline Financing & 11.8 & 4.8 & 7.0 & 1.6 & 0.7 & 0.2 & 0.3 & -7.0 & -10.9 \\
\hline Domestic financing (net) & 7.4 & -1.3 & 4.1 & 1.4 & -0.2 & 0.1 & -0.3 & -7.1 & -11.1 \\
\hline Of which: bank financing & 6.1 & -1.0 & 6.7 & 0.9 & 0.2 & 0.9 & 0.9 & -4.0 & -7.4 \\
\hline External financing & 4.2 & 3.4 & 2.2 & 0.3 & 0.9 & 0.1 & 0.5 & 0.1 & 0.2 \\
\hline Of which: oil account & $\ldots$ & $\ldots$ & $\ldots$ & 0.0 & 0.0 & -0.5 & -0.7 & -1.6 & -1.8 \\
\hline Errors and omissions 4/ & 0.2 & 2.7 & 0.7 & $\ldots$ & $\ldots$ & $\ldots$ & $\ldots$ & $\ldots$ & $\ldots$ \\
\hline Financing gap 5/ & $\ldots$ & $\ldots$ & $\ldots$ & $\ldots$ & $\ldots$ & $\ldots$ & $\ldots$ & 0.2 & 0.5 \\
\hline \multicolumn{10}{|l|}{ Memorandum items: } \\
\hline Non-oil primary balance including grants & -9.0 & -1.8 & -3.8 & -1.3 & -0.7 & -1.7 & -2.1 & -2.9 & -3.5 \\
\hline Oil revenue (millions of US\$) & $\ldots$ & $\ldots$ & $\ldots$ & $\ldots$ & $\ldots$ & $\ldots$ & $\ldots$ & $\ldots$ & 364.4 \\
\hline Oil account balance e.o.p. (millions of US\$) & $\ldots$ & $\ldots$ & $\ldots$ & $\ldots$ & $\ldots$ & 9.8 & 15.0 & 34.9 & 39.3 \\
\hline Total public debt e.o.p. & $\ldots$ & 185.6 & 158.1 & $\ldots$ & $\ldots$ & $\ldots$ & $\ldots$ & $\ldots$ & 130.0 \\
\hline Of which: central government domestic debt (including payment arrears) & $\ldots$ & 48.0 & 43.6 & $\ldots$ & $\ldots$ & $\ldots$ & $\ldots$ & $\ldots$ & 26.4 \\
\hline Stock of Treasury bills (billions of UM) & $\ldots$ & $\ldots$ & 55.4 & 61.6 & 60.6 & 56.6 & 57.4 & 40.3 & 36.9 \\
\hline Of which: commercial banks & $\ldots$ & $\ldots$ & 52.3 & 55.8 & 54.0 & 55.8 & 55.8 & 37.4 & 29.8 \\
\hline Stock of (identified) domestic arrears (billions of UM) 6/ & $\ldots$ & 55.4 & 40.0 & 41.2 & 33.8 & 38.7 & 34.7 & 22.2 & 14.4 \\
\hline $\begin{array}{l}\text { Idem, in months of non-wage, non-interest expenditure (excluding foreign- } \\
\text { financed investment) }\end{array}$ & $\ldots$ & 7.0 & 4.6 & 4.1 & 3.4 & 3.9 & 3.5 & 2.2 & 1.4 \\
\hline $\begin{array}{l}\text { Treasury float (billions of UM) } 7 / \\
\text { Idem, in months of non-wage, non-interest expenditure (excluding foreign- }\end{array}$ & $\ldots$ & 21.2 & 8.7 & 10.0 & 2.5 & 10.0 & 7.0 & 7.0 & 7.0 \\
\hline financed investment) & $\ldots$ & $\cdots$ & 1.0 & 1.5 & 0.4 & 1.0 & 0.6 & 0.6 & 0.7 \\
\hline Social expenditure (current and capital) & $\ldots$ & $\ldots$ & 6.9 & $\ldots$ & $\ldots$ & $\ldots$ & $\ldots$ & $\ldots$ & 8.1 \\
\hline Poverty reducing expenditure $8 /$ & & & & $\ldots$ & 1.5 & $\ldots$ & $\ldots$ & $\ldots$ & 5.3 \\
\hline Foreign financed public investment (outside the budget) $9 /$ & $\ldots$ & $\ldots$ & 0.2 & $\ldots$ & $\ldots$ & $\ldots$ & $\ldots$ & $\ldots$ & 2.8 \\
\hline
\end{tabular}

Sources: Mauritanian authorities; and Fund staff estimates and projections.

$1 /$ Cash basis adjusted for extrabudgetary spending until 2004, payment order basis thereafter.

2/ On a cumulative basis.

3/ Including transfers to public entities outside central government.

4/ A significant increase in errors and omissions in 2004 is probably related to arrears on extra-budgetary expenditure.

5/ Expected to be covered by possible MDRI relief.

6/ Treasury "float" plus payment obligations—which have neither been budgeted nor paid for-that have been acknowledged by the state.

7/ Outstanding payment orders registered by the Treasury.

8/ Based on the newly-introduced functional classification, which does not yet include foreign-financed projects.

9/ Not included in central government's foreign-financed investment. 
Table 3. Mauritania: Monetary Accounts, 2003-06 (End period stocks; in billions of ouguiya)

\begin{tabular}{|c|c|c|c|c|c|c|c|c|c|}
\hline & 2003 & 2004 & 2005 & & & 200 & & & \\
\hline & Rev & & Prel. & $\mathrm{Ma}$ & & $\mathrm{Ju}$ & & Sep. & Dec. \\
\hline & & & FIE. & Prog. & Est. & Prog & Proj. & Proj. & Proj. \\
\hline Monetary survey & & & & & & & & & \\
\hline Net foreign assets & -57.5 & -68.5 & -71.0 & -76.5 & -70.2 & -71.1 & -60.3 & -39.3 & -15.8 \\
\hline BCM & -48.3 & -47.0 & -38.9 & -41.6 & -37.5 & -36.1 & -33.9 & -23.5 & -5.9 \\
\hline Commercial banks & -9.1 & -21.4 & -32.1 & -34.9 & -32.7 & -35.0 & -26.4 & -15.8 & -9.9 \\
\hline Net domestic assets & 175.7 & 202.7 & 224.8 & 237.4 & 229.5 & 241.0 & 230.2 & 211.9 & 193.9 \\
\hline Domestic credit & 198.9 & 264.0 & 303.1 & 318.5 & 310.2 & 322.1 & 310.2 & 292.9 & 274.9 \\
\hline Net credit to the government & 82.0 & 129.92 & 159.7 & 167.1 & 161.2 & 167.1 & 165.3 & 136.9 & 117.3 \\
\hline o.w. Net credit to government (central government) & 82.0 & 129.9 & 162.9 & 168.3 & 164.2 & 168.3 & 168.3 & 139.9 & 120.3 \\
\hline Claims & 129.9 & 143.4 & 181.9 & 185.4 & 182.7 & 185.4 & 184.5 & 156.1 & 136.5 \\
\hline Deposits & -47.9 & -13.6 & -22.3 & -18.4 & -21.5 & -18.4 & -19.3 & -19.3 & -19.3 \\
\hline Credit to the economy & 116.9 & 134.1 & 143.5 & 151.4 & 149.0 & 155.1 & 144.9 & 156.0 & 157.6 \\
\hline Other items net & -23.2 & -61.3 & -78.4 & -81.1 & -80.7 & -81.1 & -80.0 & -81.0 & -81.0 \\
\hline Broad Money & 118.3 & 134.3 & 153.8 & 160.9 & 159.3 & 169.9 & 169.9 & 172.6 & 178.1 \\
\hline Currency in circulation & 44.3 & 42.8 & 49.1 & 51.3 & 51.8 & 53.7 & 53.7 & 54.2 & 55.4 \\
\hline Demand deposits & 55.8 & 68.0 & 79.2 & 82.9 & 80.3 & 88.0 & 88.0 & 89.8 & 93.1 \\
\hline Term deposits & 18.1 & 23.5 & 25.5 & 26.7 & 27.2 & 28.2 & 28.2 & 28.6 & 29.6 \\
\hline Monetary authorities & & & & & & & & & \\
\hline Net foreign assets & -48.3 & -47.0 & -38.9 & -41.6 & -37.5 & -36.1 & -33.9 & -23.5 & -5.9 \\
\hline Assets & 8.4 & 10.0 & 18.9 & 14.9 & 20.5 & 18.7 & 17.6 & 25.2 & 40.7 \\
\hline Liabilities & -56.7 & -57.0 & -57.7 & -56.4 & -58.0 & -54.9 & -51.5 & -48.8 & -46.6 \\
\hline Net domestic assets & 109.7 & 117.0 & 106.9 & 114.6 & 109.5 & 114.6 & 112.3 & 102.3 & 87.3 \\
\hline Net credit to the government $3 /$ & 76.5 & 122.22 & 112.6 & 116.5 & 112.5 & 116.5 & 114.7 & 104.7 & 92.7 \\
\hline o.w. Treasury & 76.5 & 122.2 & 115.9 & 117.8 & 115.6 & 117.8 & 117.8 & 107.8 & 95.8 \\
\hline Claims & 124.3 & 135.3 & 134.6 & 134.6 & 133.7 & 134.6 & 133.7 & 123.7 & 111.7 \\
\hline Deposits 3/ & -47.8 & -13.1 & -22.0 & -18.1 & -21.2 & -18.1 & -19.0 & -19.0 & -19.0 \\
\hline Claims on private sector & 2.7 & 3.3 & 3.5 & 3.5 & 1.9 & 3.5 & 1.9 & 1.9 & 1.9 \\
\hline Claims on commercial banks & 1.3 & 0.8 & 0.0 & 3.0 & 0.0 & 3.0 & 3.0 & 3.0 & 0.0 \\
\hline Other items net & 29.2 & -9.22 & -9.2 & -8.5 & -5.0 & -8.5 & -7.3 & -7.3 & -7.3 \\
\hline Reserve money & 61.4 & 69.9 & 68.0 & 73.0 & 72.0 & 78.4 & 78.4 & 78.8 & 81.4 \\
\hline Currency in circulation & 44.3 & 42.8 & 49.1 & 51.3 & 51.8 & 53.7 & 53.7 & 54.2 & 55.4 \\
\hline Reserves of banks & 17.1 & 27.1 & 18.9 & 21.7 & 20.2 & 24.7 & 24.7 & 24.6 & 26.0 \\
\hline Commercial banks & & & & & & & & & \\
\hline Net foreign assets & -9.1 & -21.4 & -32.1 & -34.9 & -32.7 & -35.0 & -26.4 & -15.8 & -9.9 \\
\hline Assets & 6.8 & 7.8 & 16.5 & 16.5 & 18.7 & 16.5 & 16.5 & 16.5 & 16.5 \\
\hline Liabilities & -16.0 & -29.3 & -48.6 & -51.4 & -51.5 & -51.5 & -42.9 & -32.3 & -26.4 \\
\hline Net domestic assets & 83.1 & 112.9 & 136.8 & 144.5 & 140.2 & 151.2 & 142.6 & 134.2 & 132.6 \\
\hline Domestic credit & 119.7 & 138.6 & 187.0 & 198.5 & 195.8 & 202.1 & 193.5 & 186.2 & 180.2 \\
\hline Net credit to the government & 5.4 & 7.7 & 47.0 & 50.5 & 48.7 & 50.5 & 50.5 & 32.1 & 24.5 \\
\hline Claims & 5.6 & 8.1 & 47.4 & 50.9 & 49.0 & 50.9 & 50.9 & 32.5 & 24.9 \\
\hline o.w. Treasury bills & 8.1 & 13.6 & 52.3 & 55.8 & 52.4 & 55.8 & 55.8 & 37.4 & 29.8 \\
\hline Deposits & -0.1 & -0.4 & -0.3 & -0.3 & -0.3 & -0.3 & -0.3 & -0.3 & -0.3 \\
\hline Credit to the economy & 114.2 & 130.9 & 140.0 & 147.9 & 147.1 & 151.6 & 143.0 & 154.1 & 155.7 \\
\hline Net claims on the BCM & 15.8 & 26.4 & 18.9 & 18.7 & 20.2 & 21.7 & 21.7 & 21.6 & 26.0 \\
\hline Total Reserves & 17.1 & 27.1 & 18.9 & 21.7 & 20.2 & 24.7 & 24.7 & 24.6 & 26.0 \\
\hline Credit from BCM & -1.3 & -0.8 & 0.0 & -3.0 & 0.0 & -3.0 & -3.0 & -3.0 & 0.0 \\
\hline Other items net & -52.4 & -52.0 & -69.2 & -72.6 & -75.7 & -72.6 & -72.6 & -73.6 & -73.6 \\
\hline Deposit liabilities to nonbank residents & 74.0 & 91.5 & 104.7 & 109.6 & 107.5 & 116.2 & 116.2 & 118.4 & 122.7 \\
\hline Memorandum items: & & & & & & & & & \\
\hline Currency/Deposits (in percent) & 59.9 & 46.8 & 46.9 & 46.8 & 48.2 & 46.2 & 46.2 & 45.8 & 45.1 \\
\hline Broad money (in percent) $4 /$ & 25.5 & 13.5 & 14.6 & 4.6 & 3.6 & 10.5 & 10.5 & 12.2 & 15.8 \\
\hline Credit to the economy (in percent) $4 /$ & 21.9 & 14.7 & 7.0 & 5.5 & 3.9 & 8.1 & 1.0 & 8.7 & $\begin{array}{r}9.8 \\
16.9\end{array}$ \\
\hline $\begin{array}{l}\text { Financing of the economy (in percent) } 5 / \\
\text { Foreign assets of the BCM (in millions of US\$) }\end{array}$ & 31.7 & 38.8 & 70.2 & 55.4 & 76.5 & 52.2 & 65.4 & 93.9 & $\begin{array}{r}16.9 \\
151.6\end{array}$ \\
\hline Gross international reserves (in millions of US $\$$ ) 6/ & 31.7 & 38.8 & 70.2 & 46.6 & 67.1 & 41.1 & 49.4 & 92.9 & 151.6 \\
\hline Net international reserves (in millions of US $\$$ ) $6 /$ & -197.7 & -210.7 & -162.5 & -179.5 & -168.5 & -161.6 & -158.6 & -108.2 & -41.6 \\
\hline Net foreign assets of commercial banks (in millions of US\$) & -34.4 & -83.6 & -119.4 & -130.0 & -121.9 & -130.2 & -98.1 & -58.7 & -36.8 \\
\hline
\end{tabular}

Sources: Mauritanian authorities; and Fund staff estimates and projections.

1/ At end-2005 program exchange rates.

2/ BCM foreign exchange losses, previously recorded with "other items net" (accumulated over a number of years), were recognized as credits to government at end-2004.

$3 /$ Including public entities' deposits with the BCM.

4 / Change relative to the end of the previous year.

5/ Reflecting the change in credit to the economy + the reduction of government arrears to enterprises as a percentage of credit to the economy at end-2005.

6/ Reflecting repayment of two noncomplying disbursements (SDR 12.14 million) in the second quarter of 2006. 
Table 4. Mauritania: Balance of Payments, 2003-11 (In millions of U.S. dollars, unless otherwise indicated)

\begin{tabular}{|c|c|c|c|c|c|c|c|c|c|}
\hline & 2003 & 2004 & 2005 & 2006 & 2007 & 2008 & 2009 & 2010 & 2011 \\
\hline & \multicolumn{2}{|c|}{ Revised } & \multicolumn{3}{|l|}{ Prel. } & \multicolumn{2}{|c|}{ Projections } & & \\
\hline Trade balance & -223.8 & -483.8 & -783.3 & 683.3 & 927.9 & 947.4 & 1138.0 & 1222.2 & 1149.2 \\
\hline Exports & 318.2 & 439.6 & 604.1 & 1892.0 & 2384.4 & 2538.1 & 2608.3 & 2690.1 & 2639.8 \\
\hline Of which: Iron ore & 163.9 & 230.2 & 389.4 & 467.5 & 505.4 & 498.7 & 481.4 & 422.9 & 370.1 \\
\hline Fish & 131.5 & 172.6 & 172.7 & 187.0 & 200.1 & 209.4 & 218.4 & 227.5 & 236.7 \\
\hline Crude oil & $\ldots$ & $\ldots$ & $\ldots$ & 1119.4 & 1468.5 & 1588.8 & 1659.4 & 1778.4 & 1756.8 \\
\hline Copper & $\ldots$ & $\ldots$ & $\ldots$ & 67.5 & 99.9 & 81.0 & 70.2 & 64.8 & 58.3 \\
\hline Gold & $\ldots$ & $\ldots$ & $\ldots$ & 18.0 & 75.9 & 119.6 & 125.4 & 127.9 & 129.2 \\
\hline Imports, fob & -542.1 & -923.4 & -1387.4 & -1208.8 & -1456.5 & -1590.7 & -1470.3 & -1467.9 & -1490.5 \\
\hline Petroleum products & -100.3 & -145.0 & -196.4 & -242.9 & -285.6 & -306.8 & -318.4 & -326.5 & -339.6 \\
\hline Equipment for mining and extractive industries $1 /$ & -182.7 & -414.9 & -817.3 & -547.1 & -712.7 & -774.1 & -595.3 & -555.0 & -541.5 \\
\hline Other & -259.1 & -363.4 & -373.7 & -418.8 & -458.1 & -509.8 & -556.6 & -586.5 & -609.4 \\
\hline Services and income (net) & -84.8 & -142.0 & -263.0 & -698.9 & -836.0 & -907.2 & -1028.4 & -1100.4 & -1049.0 \\
\hline Services (net) & -142.5 & -207.6 & -327.6 & -333.4 & -355.5 & -387.5 & -454.3 & -502.7 & -517.1 \\
\hline Credit & 44.2 & 52.0 & 62.6 & 117.4 & 119.0 & 120.9 & 122.7 & 124.6 & 126.5 \\
\hline Of which: Individual fishing licenses 2/ & 27.5 & 22.1 & 31.6 & 84.4 & 85.0 & 85.9 & 86.7 & 87.4 & 88.2 \\
\hline Debit & -186.6 & -259.6 & -390.2 & -450.7 & -474.6 & -508.4 & -577.0 & -627.3 & -643.6 \\
\hline Income (net) & 57.7 & 65.6 & 64.6 & -365.6 & -480.5 & -519.7 & -574.1 & -597.7 & -531.9 \\
\hline Credit & 94.6 & 104.5 & 108.6 & 3.4 & 11.1 & 22.1 & 32.8 & 43.6 & 52.8 \\
\hline Of which: EU fishing compensation 2/ & 93.4 & 103.2 & 107.1 & 0.0 & 0.0 & 0.0 & 0.0 & 0.0 & 0.0 \\
\hline Capital income on oil account & & & & 0.4 & 3.3 & 7.2 & 13.9 & 23.2 & 30.5 \\
\hline Debit & -36.9 & -38.9 & -44.0 & -369.0 & -491.6 & -541.7 & -607.0 & -641.3 & -584.7 \\
\hline Of which: Interest due on public debt & -36.9 & -38.9 & -41.7 & -40.4 & -40.0 & -37.8 & -35.2 & -33.5 & -31.4 \\
\hline Oil sector profits and salaries $3 /$ & $\ldots$ & $\ldots$ & $\ldots$ & -279.6 & -364.7 & -394.0 & -465.0 & -493.3 & -440.7 \\
\hline Current transfers (net) & 133.2 & 108.7 & 112.3 & 127.3 & 103.3 & 98.6 & 95.5 & 93.9 & 87.2 \\
\hline Private unrequited transfers (net) & 45.0 & 47.7 & 40.7 & 47.0 & 47.5 & 48.2 & 48.8 & 49.3 & 49.8 \\
\hline Official transfers & 88.3 & 61.0 & 71.6 & 80.3 & 55.8 & 50.4 & 46.7 & 44.5 & 37.3 \\
\hline Of which: Multilateral HIPC assistance & 35.2 & 30.9 & 28.7 & 27.2 & 23.6 & 21.3 & 21.6 & 20.5 & 15.5 \\
\hline Current account balance & -175.3 & -517.1 & -934.0 & 111.6 & 195.2 & 138.8 & 205.1 & 215.6 & 187.4 \\
\hline Capital and financial account & 140.7 & 427.1 & 813.0 & 33.0 & -42.5 & 3.9 & -38.0 & -19.8 & -91.1 \\
\hline Capital account 4/ & 0.0 & 15.5 & 0.0 & 122.6 & 0.0 & 0.0 & 0.0 & 0.0 & 0.0 \\
\hline Financial account & 140.7 & 411.6 & 813.0 & -89.7 & -42.5 & 3.9 & -38.0 & -19.8 & -91.1 \\
\hline Direct investment (net) & 101.9 & 391.6 & 863.6 & -59.7 & -53.1 & -31.2 & -45.7 & -57.4 & -130.4 \\
\hline Of which: Oil exploration (net) 3/ & 95.3 & 362.0 & 731.1 & -159.7 & -107.3 & -90.4 & -109.9 & -149.1 & -243.3 \\
\hline Official medium- and long-term loans & 1.7 & 19.9 & -28.0 & 71.4 & 34.0 & 48.0 & 21.3 & 21.5 & 21.7 \\
\hline Disbursements & 86.9 & 95.2 & 52.6 & 152.6 & 121.3 & 133.2 & 108.1 & 110.8 & 109.4 \\
\hline Amortization & -85.2 & -75.3 & -80.6 & -81.2 & -87.3 & -85.2 & -86.8 & -89.3 & -87.7 \\
\hline Other financial flows & 37.1 & 0.1 & -22.5 & -101.3 & -23.4 & -12.9 & -13.6 & 16.0 & 17.6 \\
\hline Errors and omissions & -92.4 & -19.2 & 47.1 & 10.0 & $\cdots$ & $\ldots$ & $\cdots$ & $\ldots$ & $\ldots$ \\
\hline Overall balance & -127.0 & -109.2 & -73.8 & 154.6 & 152.7 & 142.7 & 167.1 & 195.8 & 96.2 \\
\hline Financing & 127.0 & 109.2 & 73.8 & -154.6 & -152.7 & -142.7 & -167.1 & -195.8 & -96.2 \\
\hline Net foreign assets & 61.1 & 50.9 & 10.7 & -246.5 & -215.1 & -199.5 & -223.9 & -252.3 & -148.9 \\
\hline Central bank (net) & 46.5 & 1.7 & -29.4 & -124.6 & -165.4 & -110.2 & -46.8 & -49.8 & -49.2 \\
\hline Assets & 42.2 & -7.2 & -33.0 & -80.2 & -139.4 & -78.2 & -30.2 & -36.0 & -38.4 \\
\hline Liabilities & 4.3 & 8.8 & 3.6 & -44.4 & -26.0 & -32.1 & -16.6 & -13.8 & -10.8 \\
\hline Commercial banks (net) & 14.6 & 49.2 & 40.1 & -82.6 & 14.7 & 13.2 & 13.9 & 8.2 & 6.7 \\
\hline Oil account & $\ldots$ & $\ldots$ & $\ldots$ & -39.3 & -64.3 & -102.5 & -191.0 & -210.7 & -106.4 \\
\hline Exceptional financing & 65.9 & 58.3 & 63.1 & 59.5 & 62.4 & 56.8 & 56.8 & 56.5 & 52.7 \\
\hline Financing gap (shortfall +) 5/ & $\ldots$ & $\ldots$ & $\ldots$ & 32.4 & 0.0 & 0.0 & 0.0 & 0.0 & 0.0 \\
\hline Of which: Arab Monetary Fund & $\ldots$ & $\ldots$ & $\ldots$ & 22.4 & 0.0 & 0.0 & 0.0 & 0.0 & 0.0 \\
\hline \multicolumn{10}{|l|}{ Memorandum items: } \\
\hline Current account balance (in percent of annual GDP) & -13.6 & -34.6 & -49.9 & 3.5 & 5.2 & 3.4 & 4.7 & 4.7 & 4.0 \\
\hline Idem, excluding oil and other mining (except SNIM) & -7.1 & -11.9 & -7.8 & -8.9 & -10.4 & -11.6 & -11.8 & -12.6 & -13.6 \\
\hline Gross official reserves & 31.7 & 38.8 & 70.2 & 151.6 & 291.0 & 369.2 & 399.4 & 435.4 & 473.9 \\
\hline In months of imports 6 / & 0.4 & 0.5 & 0.7 & 1.4 & 2.5 & 3.0 & 3.2 & 3.4 & 3.5 \\
\hline Oil account & $\ldots$ & $\ldots$ & $\ldots$ & 39.3 & 103.6 & 206.1 & 397.1 & 607.9 & 714.3 \\
\hline Net BOP impact of oil operations & 10.6 & 38.9 & 49.3 & 373.3 & 437.7 & 480.9 & 565.3 & 610.2 & 558.8 \\
\hline PPG external debt (in percent of annual GDP) 7/ & 150.2 & 137.6 & 114.6 & 69.8 & 59.5 & 55.6 & 52.8 & 50.5 & 50.2 \\
\hline $\begin{array}{l}\text { Debt service after HIPC debt relief (in percent of } \\
\text { exports of goods and services) } 7 /\end{array}$ & 11.0 & 8.7 & 6.7 & 4.2 & 2.7 & 2.9 & 2.2 & 2.1 & 2.2 \\
\hline
\end{tabular}

Sources: Data provided by the Mauritanian authorities; and Fund staff estimates and projections.

1/ Figures based on staff estimates and projections, for lack of data provision from the respective FDI companies.

2/ From 2006 onward, the shortfall from the expiring EU fisheries agreement is assumed to be partially offset by higher sales of individual fishing licenses.

3/ Oil-related outflows comprise profit transfers and negative FDI, the latter capturing the amortization of investment (cost oil) in line with the March 2006 agreement

between Mauritania and the foreign oil operator.

4/ The capital account balance in 2006 reflects an oil-related signature bonus of USD 100 million.

$5 /$ The financing gap pertains only to the second half of 2006; its unidentified part could be filled by MDRI relief.

6/ Imports of goods and services for the year ahead, excluding oil exploration and other mining related imports (except SNIM).

7/ Excluding passive debt. The projections also do not yet incorporate the impact of possible MDRI relief. 
Table 5. Mauritania: Quantitative Indicators for the Staff-Monitored Program at end-March and end-June 2006 1/

(cumulative change from end-December 2005, unless otherwise indicated)

\begin{tabular}{|c|c|c|c|c|c|c|}
\hline & \multicolumn{2}{|c|}{ End-Decembec 2005} & \multicolumn{3}{|c|}{ End-Marech 2006} & \multirow{2}{*}{$\frac{\text { End-June } 2006}{\text { Target }}$} \\
\hline & Original & Revised & Target & Adjusted Target & Actual & \\
\hline \multicolumn{7}{|l|}{ Quantitative targets } \\
\hline Net international reserves of the BCM (floor); in US\$ million & -164.2 & -162.5 & -17.0 & -11.1 & -3.7 & 0.9 \\
\hline Net domestic assets of the BCM (ceiling); in UM billion & 107.4 & 106.9 & 7.2 & 5.6 & 2.1 & 7.2 \\
\hline Balance of government nonoil operations (floor); in UM billion & $\ldots$ & $\ldots$ & -10.0 & -10.0 & -2.2 & -15.4 \\
\hline Treasury float (ceiling); in UM billion & 10.1 & 8.7 & 0.0 & 0.0 & -6.6 & 0.0 \\
\hline $\begin{array}{l}\text { Medium- and long-term nonconcessional borrowing contracted or guaranteed } \\
\text { by the government (continuous ceiling); in US\$ million }\end{array}$ & $\cdots$ & $\cdots$ & 0.0 & 0.0 & 0.0 & 0.0 \\
\hline Payments arrears on the official external debt (continuous ceiling); in US\$ million & $\ldots$ & $\ldots$ & 0.0 & 0.0 & 0.0 & 0.0 \\
\hline \multicolumn{7}{|l|}{ Reference projections for the adjustors (in US\$ million) } \\
\hline & & & Projection & Actual & & Projection \\
\hline Net external assistance & & & -0.8 & -0.2 & & -9.4 \\
\hline \multicolumn{7}{|l|}{ Disbursement of foreign currency loans and grants } \\
\hline (budgetary aid; excluding HIPC and project grants) & & & 4.1 & 4.2 & & 4.1 \\
\hline Official external debt service (cash; including interest on foreign liabilities of the BCM) & & & 4.9 & 4.4 & & 13.5 \\
\hline Impact of any additional debt relief obtained after December 31, 2005 & & & 0.0 & 0.0 & & 0.0 \\
\hline Transfers from the National Hydrocarbon Revenue Fund to the budget & & & 4.8 & 10.1 & & 58.5 \\
\hline \multicolumn{7}{|l|}{ Memorandum items } \\
\hline UM/US\$ exchange rate (program) & 268.6 & & & & & \\
\hline
\end{tabular}

Sources: Mauritanian authorities and Fund staff.

1/ For definitions, see the Technical Memorandum of Understanding included in Country Report 06/255 (Attachment III). 
Table 6: Mauritania: Structural Indicators for the Staff-Monitored Program, January-June 2006

- Transmission of the monthly TOFE to IMF staff with a lag of one month, based on the Treasury balance and reconciled with the BCM accounts on a monthly basis; cumulative data from the start of the year.

End-March TOFE available at end-April 2006 1/

Done (through

Transmission to Fund staff of the preliminary report on the analysis of the revised economic data

End-April 2006 end-April) for 1992-2004

- Transmission to Fund staff of the final audit report on the BCM accounts for 2003 and 2004.

Sources: Mauritanian authorities and Fund staff.

1/ Subsequent monthly reports will be submitted to Fund staff on a monthly basis. 
Table 7. Mauritania: Remedial Actions for MDRI Qualification

\section{Resolution of the data issues}

Implemented: Monetary and official reserves data for 1992-2004, have been revised; BCM's financial statements for 2003, 2004, and 2005 have been audited.

\section{Six months of sound macroeconomic policies}

Implemented: The six-month period ran from October 2005 through March 2006.

\section{Remedial actions in the areas of budget formulation execution and reporting}

1. Preparation of the monthly TOFE with a lag of one month, based on the Treasury balance and reconciled with the central bank accounts on a monthly basis, cumulative data from the start of the year, beginning with end-March TOFE (end-April 2006):

Implemented: Budget executions reports (TOFE) through April have been transmitted to staff.

2. Updating of the MTEF and its integration in the budget cycle:

. Implemented: A draft of the Medium-Term Budget Framework was discussed during the mission.

3. Elimination of all extrabudgetary spending:

Implemented: The 2006 budget allocations expanded compared with the 2005 budget with a view to accommodating all the justified spending that previously gave rise to extra-budgetary slippages. Budget execution procedures were tightened: elimination of treasury debits without pre-existing budget allocation, stricter adherence to the documentation requirements by the Treasury, tightening of procedures for domestically-financed investment spending.

4. Sufficient progress in the elimination of payments arrears and regularization of the public accounts:

Implemented: The arrears reduction target for the first quarter was observed with a wide margin. Final balance of the Treasury accounts for 2005 was established after the closure of complementary period for the execution of the 2005 budget in February 2006. Public accounts for $2003-05$ are being prepared by the Treasury for submission to the General Audit Office) by end-June 2006.

5. Improvement of public expenditure tracking (including poverty-reducing expenditure) using a functional classification:

Implemented: Functional classification was adopted, including a module enabling the tracking of (the domestically-financed) poverty-reducing expenditure (foreignfinanced projects are to be included later on).

Sources: Mauritanian authorities and Fund staff. 
Table 8. Mauritania: Millennium Development Goals, 1990-2015 1/

\begin{tabular}{|c|c|c|c|c|c|c|}
\hline & 1990 & 1996 & 2000 & 2002 & 2004 & $\frac{\text { MDGs }}{2015}$ \\
\hline 1. Eradicate extreme poverty and hunger & \multicolumn{6}{|c|}{ (In percent of total population) } \\
\hline Overall poverty incidence & 56.6 & 54.3 & 51.0 & $\ldots$ & 46.7 & 28.3 \\
\hline Incidence of poverty in Nouakchott & 36.1 & 25.4 & 29.2 & $\ldots$ & 25.9 & \\
\hline Prevalence of child malnutrition & 47.6 & $\ldots$ & 32.0 & $\ldots$ & 30.2 & 23.8 \\
\hline 2. Achieve universal primary education & \multicolumn{6}{|c|}{ (In percent of primary school age group) } \\
\hline Gross primary enrollment ratio & 46.0 & 82.0 & 87.0 & 88.0 & 95.1 & 100.0 \\
\hline Retention rate at the entrance of the 5 th & \multicolumn{6}{|c|}{ (In percent of students enrolled in first grade) } \\
\hline grade in primary education & $\ldots$ & $\cdots$ & 55.0 & 48.0 & 48.8 & 100.0 \\
\hline 3. Promote gender equality & \multicolumn{6}{|c|}{ (In percent of total enrollment) } \\
\hline Share of girls in total primary enrollment & 42.0 & 46.0 & 48.0 & 49.0 & 49.8 & 50.0 \\
\hline 4. Reduce child mortality & \multicolumn{6}{|c|}{ (Per 1,000 live births) } \\
\hline Child mortality (under five years) & 137.0 & 122.0 & 135.0 & $\ldots$ & 123.0 & 45.7 \\
\hline 5. Improve maternal health & \multicolumn{6}{|c|}{ (For each 100,000 live births) } \\
\hline Reduce the rate of maternal mortality & $\ldots$ & $\ldots$ & 747 & $\ldots$ & $\ldots$ & $\ldots$ \\
\hline 6. Combat HIVIAIDS, malaria, and other diseases & \multicolumn{6}{|c|}{ (In percent of ages 15-24) } \\
\hline Reduce by half the incidence of HIVIAIDS & $\ldots$ & $\ldots$ & 0.5 & 0.6 & 0.5 & 1.0 \\
\hline 7. Ensure environmental sustainability & \multicolumn{6}{|c|}{ (In percent of population) } \\
\hline Access to improved water source & $\ldots$ & $\ldots$ & 60.4 & $\ldots$ & 63.7 & 60.0 \\
\hline Access to electricity & $\ldots$ & $\ldots$ & 18.0 & $\ldots$ & 23.8 & $\ldots$ \\
\hline \multicolumn{7}{|l|}{ Memorandum items: } \\
\hline Population (in millions) 2/ & 1.96 & 2.27 & 2.51 & 2.63 & 2.82 & ... \\
\hline UNDP Human Development Index & 0.387 & 0.423 & 0.449 & 0.465 & $\ldots$ & $\ldots$ \\
\hline Gini index of inequality & $\ldots$ & 0.34 & 0.39 & $\ldots$ & 0.39 & $\ldots$ \\
\hline Child vaccination rate (in percent) & $\ldots$ & 30 & 40 & 70 & 93 & $\ldots$ \\
\hline
\end{tabular}

Sources: Mauritanian authorities, World Development Indicators, and UNDP Human Development Indicators (2004).

$1 /$ Revised and updated.

2/ Estimates based on the population census data in 1988 and 2000.

Goal 1: Halve, between 1990 and 2015, the proportion of people whose income is less than US\$1 a day.

Goal 2. Ensure that, by 2015 , children will be able to complete a full course of primary schooling.

Goal 3. Eliminate gender disparity in primary and secondary education.

Goal 4. Reduce by two-thirds, between 1990 and 2015, the under-five mortality rate.

Goal 5. Reduce by three-quarters, between 1990 and 2015, the under-five mortality rate.

Goal 6. Have halted the spread of HIVIAIDS, incidence of malaria and other major diseases and begin to reverse.

Goal 7. Integrate the principles of sustainable development into country policies and programs and reverse the loss of environmental resources. Halve, by 2015, the proportion of people without sustainable access to safe drinking water. 
Table 9. Mauritania: Macroeconomic Framework, 2001-11

\begin{tabular}{|c|c|c|c|c|c|c|c|c|c|c|c|}
\hline & 2001 & 2002 & 2003 & 2004 & 2005 & 2006 & 2007 & 2008 & 2009 & 2010 & 2011 \\
\hline & \multicolumn{4}{|c|}{ Revised } & \multicolumn{3}{|l|}{ Prel. } & \multicolumn{2}{|c|}{ Projection } & & \\
\hline Economic growth and prices & \multicolumn{11}{|c|}{ (Percentage changes) } \\
\hline Real GDP & 2.9 & 1.1 & 5.6 & 5.2 & 5.4 & 19.4 & 9.6 & 7.7 & 5.9 & 4.5 & 3.5 \\
\hline Non oil Real GDP & 2.9 & 1.1 & 5.6 & 5.2 & 5.4 & 6.8 & 7.8 & 7.3 & 5.8 & 4.0 & 4.0 \\
\hline Oil real GDP & & & & & & & 24.6 & 10.3 & 6.1 & 8.5 & 0.0 \\
\hline Nominal GDP & 11.0 & 9.0 & 8.2 & 17.3 & 25.3 & 72.3 & 18.7 & 8.4 & 6.1 & 5.5 & 2.9 \\
\hline Implicit GDP deflator & 7.9 & 7.8 & 2.5 & 11.5 & 18.9 & 44.3 & 8.3 & 0.7 & 0.2 & 0.9 & -0.6 \\
\hline Consumer price index (average) & 7.7 & 5.4 & 5.3 & 10.4 & 12.1 & 6.5 & 4.7 & 3.5 & 3.5 & 3.5 & 3.5 \\
\hline Consumer price index (end-year) & 4.1 & 8.4 & 2.9 & 16.1 & 5.8 & 8.1 & 3.5 & 3.5 & 3.5 & 3.5 & 3.5 \\
\hline Investment and Savings & \multicolumn{11}{|c|}{ (In percent of GDP) } \\
\hline Gross investment & 23.9 & 24.0 & 28.1 & 47.7 & 44.5 & 25.0 & 27.5 & 28.7 & 22.0 & 19.4 & 18.4 \\
\hline Oil-related & 5.6 & 5.2 & 7.4 & 25.3 & 25.7 & 11.0 & 13.8 & 14.6 & 8.0 & 5.4 & 4.3 \\
\hline Non-oil related investment & 18.4 & 18.9 & 20.7 & 22.5 & 18.8 & 14.0 & 13.7 & 14.0 & 14.0 & 13.9 & 14.1 \\
\hline Government & 7.2 & 9.1 & 8.8 & 8.1 & 5.1 & 5.2 & 5.0 & 5.6 & 5.8 & 5.8 & 5.8 \\
\hline Nongovernment & 11.2 & 9.7 & 11.9 & 14.4 & 13.7 & 8.8 & 8.6 & 8.4 & 8.2 & 8.1 & 8.4 \\
\hline Gross savings & 12.3 & 27.1 & 14.5 & 13.1 & -5.4 & 28.5 & 32.6 & 32.0 & 26.7 & 24.1 & 22.5 \\
\hline Government & 6.3 & 8.4 & 0.4 & 5.2 & -1.1 & 10.4 & 8.5 & 8.1 & 9.7 & 10.1 & 8.8 \\
\hline Nongovernment & 6.0 & 18.7 & 14.1 & 7.9 & -4.4 & 18.1 & 24.1 & 23.9 & 17.0 & 14.0 & 13.7 \\
\hline Current account (including official transfers and oil) & -11.7 & 3.0 & -13.6 & -34.6 & -49.9 & 3.5 & 5.2 & 3.4 & 4.7 & 4.7 & 4.0 \\
\hline Balance of goods and services & -19.9 & -15.7 & -28.5 & -46.3 & -59.4 & 11.0 & 15.1 & 13.6 & 15.7 & 15.7 & 13.6 \\
\hline Exports & 35.8 & 35.3 & 28.2 & 32.9 & 35.6 & 63.0 & 66.2 & 64.8 & 62.7 & 61.3 & 59.4 \\
\hline Imports 1/ & 55.7 & 51.0 & 56.7 & 79.2 & 95.0 & 52.0 & 51.0 & 51.2 & 47.0 & 45.6 & 45.8 \\
\hline Net income 2/ & -2.9 & 11.0 & 4.5 & 4.4 & 3.5 & -11.5 & -12.7 & -12.7 & -13.2 & -13.0 & -11.4 \\
\hline Net transfers & 11.1 & 7.8 & 10.4 & 7.3 & 6.0 & 4.0 & 2.7 & 2.4 & 2.2 & 2.0 & 1.9 \\
\hline Consolidated government operations & \multicolumn{11}{|c|}{ (In percent of non-oil GDP) } \\
\hline Revenue and grants 3 / & 24.7 & 34.8 & 35.4 & 32.9 & 26.4 & 43.0 & 40.2 & 39.6 & 42.1 & 42.6 & 40.1 \\
\hline Non-oil revenue & 24.7 & 34.8 & 35.4 & 32.9 & 26.4 & 26.1 & 24.3 & 23.6 & 23.1 & 22.6 & 22.3 \\
\hline Idem, excluding grants & 20.7 & 30.4 & 30.7 & 29.7 & 24.4 & 23.6 & 21.9 & 21.5 & 21.1 & 20.7 & 20.6 \\
\hline Of which: tax revenue & 12.5 & 13.3 & 13.3 & 14.9 & 15.3 & 15.8 & 14.2 & 14.0 & 14.0 & 14.0 & 14.0 \\
\hline Expenditure and net lending & 35.0 & 37.6 & 47.2 & 37.7 & 33.5 & 35.4 & 34.6 & 35.6 & 35.9 & 35.8 & 35.5 \\
\hline Primary expenditure & 32.3 & 35.2 & 44.4 & 34.7 & 30.2 & 32.4 & 31.8 & 33.3 & 34.1 & 34.2 & 34.2 \\
\hline Current & 19.9 & 18.3 & 28.3 & 21.4 & 22.2 & 22.1 & 21.4 & 21.7 & 22.2 & 22.2 & 22.2 \\
\hline Capital 4/ & 13.2 & 13.2 & 13.0 & 10.9 & 7.4 & 10.3 & 10.5 & 11.7 & 11.9 & 12.0 & 12.0 \\
\hline Interest (gross) & 2.7 & 2.5 & 2.7 & 3.0 & 3.2 & 3.0 & 2.7 & 2.3 & 1.9 & 1.6 & 1.3 \\
\hline Overall balance & -10.3 & -2.9 & -11.8 & -4.8 & -7.0 & 7.6 & 5.6 & 4.0 & 6.1 & 6.8 & 4.6 \\
\hline Non-oil balance excluding grants & -14.3 & -7.2 & -16.4 & -8.0 & -9.1 & -11.8 & -12.6 & -14.1 & -14.9 & -15.1 & -14.9 \\
\hline Non-oil balance including grants & -10.3 & -2.9 & -11.8 & -4.8 & -7.0 & -9.3 & -10.3 & -12.0 & -12.8 & -13.2 & -13.2 \\
\hline Non-oil primary balance (including grants) & -7.7 & -0.4 & -9.0 & -1.8 & -3.8 & -6.4 & -7.5 & -9.8 & -11.0 & -11.6 & -11.9 \\
\hline \multicolumn{12}{|l|}{ Memorandum items: } \\
\hline Nominal GDP (in billions of ouguiyas) & 286.7 & 312.4 & 338.0 & 396.6 & 497.0 & 856.5 & $1,016.3$ & $1,102.0$ & $1,169.1$ & $1,233.0$ & $1,269.0$ \\
\hline External public debt outstanding (in US\$ million) 5/ & $1,991.3$ & $1,826.8$ & $1,930.5$ & $2,056.9$ & $2,143.6$ & $2,226.9$ & $2,252.2$ & $2,280.4$ & $2,297.8$ & $2,318.0$ & $2,340.6$ \\
\hline Domestic debt vis-à-vis the BCM (UM billion) & & & & 131.1 & 131.1 & 111.0 & 87.0 & 69.2 & 66.4 & 63.6 & 30.8 \\
\hline Oil account (US\$ million) & & $\ldots$ & $\ldots$ & 年 & $\ldots$ & 39.3 & 103.6 & 206.1 & 397.1 & 607.9 & 714.3 \\
\hline Gross official reserves of the BCM (US\$ million) & 39.6 & 73.9 & 31.7 & 38.8 & 70.2 & 151.6 & 291.0 & 369.2 & 399.4 & 435.4 & 473.9 \\
\hline Idem, in months of imports & 0.9 & 1.4 & 0.4 & 0.5 & 0.7 & 1.4 & 2.5 & 3.0 & 3.2 & 3.4 & 3.5 \\
\hline GNP per capita (US\$) & 265.0 & 359.0 & 498.6 & 565.7 & 685.5 & 976.3 & $1,115.5$ & $1,181.7$ & $1,216.9$ & $1,255.8$ & $1,267.5$ \\
\hline Population (millions) & 2.6 & 2.6 & 2.7 & 2.8 & 2.8 & 2.9 & 3.0 & 3.0 & 3.1 & 3.2 & 3.3 \\
\hline WEO baseline (APSP), May 19, 2006 & $\ldots$ & $\ldots$ & $\ldots$ & $\ldots$ & $\ldots$ & 66.5 & 69.8 & 68.5 & 67.5 & 66.8 & 66.0 \\
\hline Average daily production of oil (thousands of barrels) & $\cdots$ & $\cdots$ & $\ldots$ & $\cdots$ & $\ldots$ & 58.7 & 63.0 & 69.5 & 73.8 & 80.0 & 80.0 \\
\hline
\end{tabular}

Sources: Mauritanian authorities; and Fund staff estimates and projections.

1/ The relatively high imports to GDP ratio reflects the development phase of oil exploration, which peaks in 2005 and declines thereafter. 2/ Includes fish license payments.

3/ Multilateral HIPC assistance is shown as grants.

4/ Starting in 2006, includes public investment with the use of foreign financing on-lent by the central government.

5/ Including debt subject to MDRI and HIPC relief; excluding passive debt. 
Table 10. Mauritania: Public and Publicly Guaranteed (PPG) External Debt and Debt Relief, 2004-07 (in millions of U.S. dollars; unless otherwise indicated)

\begin{tabular}{|c|c|c|c|c|c|}
\hline & \multirow[t]{2}{*}{2004 (Est.) $1 /$} & \multirow[t]{2}{*}{2005 (Est.) $1 /$} & \multicolumn{2}{|c|}{2006 (Proj.) } & \multirow{2}{*}{$\begin{array}{r}2007 \text { (Proj.) } \\
\text { After MDRI } 2 / \\
\end{array}$} \\
\hline & & & Before MDRI 1/ & After MDRI 21 & \\
\hline PPG External debt & $2,056.9$ & $2,143.6$ & $2,226.9$ & $1,368.2$ & $1,420.6$ \\
\hline Of which: owed to the Fund 3/ & 89.6 & 69.4 & 39.9 & 0.0 & 0.0 \\
\hline Of which: owed to IDA & 696.9 & 674.2 & 664.1 & 78.0 & 86.9 \\
\hline Of which: owed to AfDF & 259.2 & 242.9 & 240.0 & 7.3 & 7.3 \\
\hline PPG external debt to GDP (in percent) & 137.6 & 114.6 & 69.8 & 42.9 & 37.5 \\
\hline NPV of PPG external debt to GDP (in percent) & 59.4 & 53.0 & 34.2 & 21.8 & 20.5 \\
\hline
\end{tabular}

Sources: Mauritanian authorities; and Fund staff estimates and projections.

1/ Before multilateral HIPC relief on outstanding principal.

2/ After MDRI relief and multilateral HIPC relief on outstanding principal. Assuming delivery on January 1, 2006 (retroactive) for the AfDF, on June 22, 2006 for the Fund, and on October 1, 2006 for IDA.

3/ Delivery of MDRI relief on June 22, 2006 would imply a write-off of SDR 32.9 million (US\$ 47.3 million), of which SDR 2.5 million (US\$ 3.6 million) correspond to already approved HIPC relief. The amount of MDRI relief differs from the projected end-2006 stock before MDRI (US\$ 39.9 million) by the sum of principal payments scheduled between June 22 and December 31, 2006.

4/ Exports of goods and services for the year under consideration. 


\section{APPENDIX I. MaURitania: Relations With THE FUnd}

As of April 30, 2006

I. Membership Status: Joined: September 10, 1963

$\underline{\text { Article VIII }}$

II. General Resources Account:

Quota

Fund holdings of currency

Reserve Position

III. SDR Department:

Net cumulative allocation

Holdings

IV. Outstanding Purchases and Loans:

PRGF Arrangements
SDR Million

64.40

64.40

0.00

SDR Million

9.72

0.13

SDR Million

44.47
100.00

100.01

0.00

$\%$ Allocation

100.00

1.32

\% Quota

69.06
\% Quota

V. Latest Financial Arrangements:

\begin{tabular}{|c|c|c|c|c|}
\hline Type & $\begin{array}{l}\text { Approval } \\
\text { Date }\end{array}$ & $\begin{array}{l}\text { Expiration } \\
\text { Date }\end{array}$ & $\begin{array}{l}\text { Amount Approved } \\
\text { (SDR Million) }\end{array}$ & $\begin{array}{l}\text { Amount Drawn } \\
\text { (SDR Million) }\end{array}$ \\
\hline PRGF & Jul. 18, 2003 & Nov. $07,2004^{16}$ & 6.44 & 0.92 \\
\hline PRGF & Jul. 21, 1999 & Dec. 20,2002 & 42.49 & 42.49 \\
\hline PRGF & Jan. 25, 1995 & Jul. 13, 1998 & 42.75 & 42.75 \\
\hline
\end{tabular}

VI. Projected Payments to Fund (without HIPC Assistance)

(In millions of SDRs; based on existing use of resources and present holdings of SDRs):

\begin{tabular}{llllll} 
& \multicolumn{6}{c}{ Forthcoming } \\
\cline { 2 - 7 } Principal & $\underline{2006}$ & $\underline{2007}$ & $\underline{2008}$ & $\underline{2009}$ & $\underline{2010}$ \\
Charges/Interest & 0.47 & 0.92 & 7.11 & 8.50 & 6.68 \\
Total & 7.06 & 9.43 & 7.57 & 8.92 & 7.06
\end{tabular}

Projected Payments to Fund (with Board-approved HIPC Assistance)

(In millions of SDRs; based on existing use of resources and present holdings of SDRs):

Principal

Charges/Interest

Total

\begin{tabular}{lllll}
\multicolumn{5}{c}{ Forthcoming } \\
\hline$\underline{2006}$ & $\underline{2007}$ & $\underline{2008}$ & $\underline{2009}$ & $\underline{2010}$ \\
0.42 & 7.82 & 7.11 & 8.50 & 6.68 \\
4.89 & 0.51 & 0.47 & 0.43 & 0.39 \\
& 8.33 & 7.57 & 8.92 & 7.06
\end{tabular}

\footnotetext{
${ }^{16}$ Cancellation date.
} 


\section{Implementation of HIPC Initiative:}

Enhanced

I. Commitment of HIPC assistance

Framework

Decision point date

Feb. 2000

Assistance committed by all creditors (US\$ millions) ${ }^{17}$

622.00

Of which: IMF assistance (US\$ millions)

46.76

(SDR equivalent in millions)

Completion point date

Jun. 2002

II Disbursement of IMF assistance (SDR millions)

Assistance disbursed to the member

Interim assistance

16.88

Completion point balance

17.92

Additional disbursement of interest income ${ }^{18}$

Total disbursements

38.43

Decision point - point at which the IMF and the World Bank determine whether a country qualifies for assistance under the HIPC Initiative and decide on the amount of assistance to be committed.

Interim assistance - amount disbursed to a country during the period between decision and completion points, up to 20 percent annually and 60 percent in total of the assistance committed at the decision point (or 25 percent and 75 percent, respectively, in exceptional circumstances).

Completion point - point at which a country receives the remaining balance of its assistance committed at the decision point, together with an additional disbursement of interest income as defined in the footnote above. The timing of the completion point is linked to the implementation of pre-agreed key structural reforms (i.e., floating completion point).

\section{Safeguards Assessments}

A full safeguards assessment of the BCM was completed on May 21, 2004. The assessment identified serious vulnerabilities in the central bank's safeguards framework and concluded that, with the exception of appointing an international audit firm, the central bank had made

\footnotetext{
${ }^{17}$ Assistance committed under the original framework is expressed in net present value (NPV) terms at the completion point, and assistance committed under the enhanced framework is expressed in NPV terms at the decision point. Hence these two amounts cannot be added.

${ }^{18}$ Under the enhanced framework, an additional disbursement is made at the completion point corresponding to interest income earned on the amount committed at the decision point but not disbursed during the interim period.
} 
little progress in strengthening the framework since the 2002 transitional assessment of the BCM's external audit mechanism. In particular, critical vulnerabilities were found in the areas of financial reporting (including reporting of monetary data to the Fund) and controls. A number of recommendations were made to address these vulnerabilities, including with respect to audits of reserves and quarterly monetary program data, the preparation of financial statements on the basis of International Financial Reporting Standards, and measures to improve controls in reserves management. Measures have been taken in some areas, and a new timetable for the implementation of outstanding safeguards recommendations was agreed with the authorities in November 2005. The external audits of FY 2003 and FY 2004 have been completed, and it is expected that the FY 2005 audit will be finalized by end-June 2006. International Financial Reporting Standards have been adopted by the BCM Board as the financial reporting framework and it is envisaged that IFRScompliant financial statements will be prepared for FY 2006. At this stage, recommendations related to monetary program data remain relevant in the context of possible future programs.

\section{Exchange Arrangements}

The currency of Mauritania is the ouguiya (UM). The ouguiya has been de facto pegged to the U.S. dollar, despite minor adjustments to the central rate in 2004-05. Since October 24, 2005, US\$1 has been equivalent to UM 268.6. In August 2002, the BCM issued two circulars: the first sets limits on, and regulates, the handling of foreign bank notes and the second reimposes a variant of a surrender requirement where 70 percent of fishing export receipts should be repatriated via the BCM. In July 2005, this surrender requirement was reduced to 60 percent. Starting in mid-2003 the BCM suspended the previous system of foreign exchange auctions and introduced foreign exchange rationing, which constitutes a restriction on the making of payments and transfers for current international transactions under Article VIII, section 2 (a).

\section{Last Article IV Consultation}

Discussions for the 2005 Article IV consultation were held in Nouakchott, from January 8 to 22, 2005, and at headquarters from March 12 to 14, 2005. Country Report 06/247 was considered by the Executive Board on May 27, 2005. The Executive Board approved the HIPC Completion Point document for Mauritania on June 7, 2002.

\section{FSAP Participation, ROSCs and Offshore Financial Center (OFC) Assessments}

A joint Fund/Bank FSAP preparatory mission visited Nouakchott in February 2005 and requested detailed financial data, including on individual banks. Following resolution of the data issues, a full mission visited Nouakchott during February 19-March 3, 2006 to assess the soundness and vulnerabilities of the financial sector; assess the provision of financial services and identify missing services and markets; review the regulatory, legal and judicial framework; and identify policy measures to address the vulnerabilities and the obstacles to the effective provision of a broad range of financial services. The Final Report on the Fiscal 
transparency Module of the Observance of Standards and Codes (ROSC) was based on two missions, respectively conducted from May 14 to 24, 2002 and from August 6 to 13, 2002. The final fiscal ROSC report is published on the IMF website.

\section{Technical Assistance (since 2001)}

1. MFD (formerly MAE)

a. Money and banking

Follow-up TA mission on reform of monetary instruments and assessment of technical assistance needs: February 7-20, 2001.

Resident expert on banking supervision: August 1, 2001-February 2, 2003, and January 6-February 3, 2004.

TA mission on money market instruments: March 7-19, 2006.

b. Exchange system

Peripatetic TA missions by panel expert on the exchange system reform: 200102.

TA mission on foreign exchange market issues: January 9-23, 2005. Peripatetic TA missions by panel expert on foreign exchange reserves management: July13-26, 2005.

2. FAD

TA mission on tracking poverty-reducing expenditures: October 10-17, 2001.

TA mission on setting up a VAT refund system: November 18-23, 2001.

TA mission on reforming taxes on income and profits: July 7-21, 2003.

TA mission on public expenditure management: April 3-19, 2005.

TA mission on fiscal administration reform: June 14-18, 2005

\section{LEG}

TA mission on the drafting of laws to combat money laundering and the financing of terrorism: February 23-March 1, 2005.

4. STA

TA mission on monetary statistics: January 9-22, 2002.

TA mission on balance of payments statistics: June 17-30, 2003.

TA mission on GDDS: April 14-28, 2004.

TA consultant on banking and monetary statistics: November 8-22, 2005

TA mission on balance of payments statistics: April 5-18, 2006 


\section{AFRITAC}

Several TA missions in 2003-06, including on tax and customs administration, computerization of public expenditure chain, external debt management, and public finance statistics.

\section{Resident Representative}

In October 2004, Mr. Philippe Callier was assigned to Mauritania to replace Mr. Prosper Youm, whose assignment ended in July 2004. 


\section{APPENDiX II. MAURitania: Relations With THE WORLd BANK GROUP As of May 25, 2006}

\section{Partnership in Mauritania's Development Strategy}

1. Mauritania developed its Poverty Reduction Strategy (PRSP) in February 2001. Since 2001 two PRSP Progress Reports (PRs) have been prepared and discussed by the Boards of the Bretton Woods institutions in June 2002 and July 2003 respectively. ${ }^{1}$ The draft PRSP2 - for the period 2006-10 - was received in mid-May 2006, and should be finalized during the third quarter of 2006. It is based on the findings of the recently completed national household survey (EPCV 2004).

2. The World Bank and the IMF continue to cooperate closely in assisting the Government of Mauritania to implement its medium-term poverty reduction strategy with each institution taking the lead in the policy dialogue in its areas of expertise. The Bank leads the policy dialogue on sectoral structural reforms, including the financial sector, privatization and poverty monitoring and evaluation. Areas of close collaboration include the PRSP, public expenditure management, the nascent oil sector, financial sector, external debt sustainability, poverty and social impact analysis, tax reform and private sector development.

3. The Bank has officially re-engaged with Mauritania in January 2006 (in accordance with OP7.30 "dealing with de-facto governments") and is free to undertake new operations, following the coup of August 3, 2005, when the Mauritanian President Ould Sid'Ahmed Taya was ousted.

\section{Bank Group Country Assistance Strategy}

\section{The Country Assistance Strategy}

4. The World Bank supports the implementation of the government's PRSP through its Country Assistance Strategy (CAS, FY03-05 - extended to cover FY06). The CAS program of lending and non-lending operations was specifically designed to support implementation of the four strategic axes of the PRSP, with particular emphasis on capacity building. In the CAS it was assumed that a series of PRSCs would gradually become the main pillars of the lending program, but this shift did not materialize, mainly as a result of the deterioration of macro-budgetary discipline, which emerged in 2004.

5. The next CAS (FY07-10) will follow the finalization of the new PRSP. It will continue to outline a Bank program that is closely aligned with the priorities of the PRSP and

\footnotetext{
${ }^{1}$ A third PRSP-PR was not finalized in 2004 due to persisting uncertainty on key macroeconomic indicators in 2003 and 2004 (and consequently on medium-term projections).
} 
will outline the Bank's strategy for transitioning to Mauritania's possible graduation from IDA to IBRD.

\section{The Bank Portfolio}

6. To date the WB has approved 69 projects in Mauritania for a total of US $\$ 1,019$ million. The current portfolio has 8 operations for a total of US\$260.5 million, with an undisbursed balance of US\$186.96 million as of May 23, 2006. The Bank's program concentrates on rural development, urban development and social sector operations (health and education), with other specific investments in growth-stimulating sectors, such as mining, energy, and transport. In FY05 the Bank delivered a Higher Education Project (US\$15 million) and an Integrated Development Program for Irrigated Agriculture (US\$39 million). In FY06 the Bank will deliver the second Health and Nutrition Project (US\$10 million), a GEF Community-based Watershed Management project (US\$6.0 million) and two Regional projects: (i) Senegal River Basin Multi-Purpose Water Resources Development project - Credit to Mauritania (US\$31.78 million), (ii) Hydroelectric project Credit to Mauritania (US\$25.0 million). In the first quarter of FY07 the Bank will also deliver a Capacity Building Project (PRECASP - US\$13 million), and an Additional Financing Credit to the Second Mining Sector Capacity Building project (US\$5.0 million) to provide technical assistance on the oil sector.

7. The Bank's program also encompasses Economic and Sector Work (ESW), the provision of Institutional Development Facility (IDF) grants and Trust Funds (TF). A Public Expenditure Review (PER) was completed in June 2004. A PER update - which benefits from the revision of all main economic data - will be completed in FY06, along with an update of the 2003 Country Economic Memorandum (CEM), focusing chiefly on natural resources management (oil and mining). An Investment Climate Assessment (ICA) is also expected by end-FY06. The Bank provided US\$448,000 in an IDF for the Justice Sector that closed end September 2005, US\$549,825 through a PHRD to prepare a Public Sector Capacity Building project, US\$349,000 through an IDF to strengthen the public procurement function and US\$273,000 through an IDF to support the accountancy profession. A PRSP-TF (US\$496,900) closed on December 31, 2005.

\section{Main Policy Reform Areas}

8. The Bank supports the authorities in the implementation of the four pillars of the PRSP.

9. Promoting Private Sector-led Growth. One of the key objectives of the government is to accelerate the implementation of reforms geared at stimulating private sector-led growth and rendering Mauritania more attractive to foreign investors. The Bank's policy dialogue in this area focuses, inter alia, on: (a) lowering factor costs (energy, transport, labor); (b) stimulating growth in the mining sector by opening competition in iron ore production; and (c) improving the overall business climate by removing remaining barriers to 
competition and factor mobility. The Bank is also promoting the growth agenda in its rural operations, particularly through the activities supported by the PDIAIM project, which works with private sector operators in the Senegal valley area.

10. Achieving Broad-based Growth. This requires, above all, increasing productivity in the livestock and agricultural sectors, which employ a large swathe of the rural poor. In livestock, the policy dialogue focuses on the application of the new Livestock Code and the elaboration of a coherent sector strategy, paying particular attention to key sub-sectors (e.g. cattle, meat, and leather). In agriculture, attention is being paid to improving farm productivity by easing access to inputs and credit and promoting training schemes for farmers. Efforts are also being undertaken to improve living conditions at the local level (village communities) by stimulating income generating activities, expanding access to basic socio-economic services, and improving natural resource management practices. More efforts need to be made to establish a national authority dealing with the cross-cutting issue of the environment.

11. Developing Human Resources. Education. The Bank's operations and policy advice support the objectives of the National Program for the Development of the Education Sector (PNDSE 2002-10). Main actions have led to: (i) the expansion of infrastructure to boost access to schools; (ii) the recruitment of new tutors and teachers; (iii) the implementation of training schemes for teachers to strengthen education quality. Efforts are also being undertaken to support the expansion of higher education, focusing on the University of Nouakchott. Mauritania has also begun to benefit from the Education for All Fast Track Initiative to accelerate the implementation of the national education program. It received US\$7 million in 2004, and a further US\$2 million in 2005.

12. Health. Additional efforts are needed to reduce (child and maternal) mortality rates and malnutrition rates, at the levels needed to reach the MDGs by 2015. Actions - which will be also supported by the Bank mainly through the upcoming second Health and Nutrition Project - have resulted in: (i) greater access to primary health; (ii) improvements in the quality of health services, especially for the poor, (iii) the establishment of new benefit packages to attract health personnel in rural areas, and (iv) the recruitment of additional health personnel. The authorities have adopted a multi-sectoral approach to combat HIV/AIDS. The leadership for this program is located in the Prime Minister's office and has translated to date in strong cross-sectoral response at both the central and local levels.

13. Strengthening Institutions and Governance. The new Government of Mauritania has recently finalized an inter-ministerial report on governance, which incorporates many elements of the 2004 National Program of Good Governance (PNBG) and an earlier Strategy for the Strengthening of National Capacity. It is expected that this report should feed into the upcoming second PRSP. The PRECASP project selectively supports elements of the abovementioned road-map, including decentralization, modernization of public administration and strengthening of civil society capabilities. 


\section{Bank-Fund Collaboration in Specific Areas}

14. As part of its overall assistance to Mauritania - through lending, country analytical work, and technical assistance - the Bank supports policy reforms in close collaboration with the Fund, in the following areas:

15. Public Expenditure Management. The Fund and Bank jointly emphasize the need to significantly improve public expenditure management (PEM), accountability, and transparency, notably following the deterioration in macroeconomic management, which emerged in 2004. However, recent evidence points to substantial progress on PEM key areas. Based on this progress, the Bank has prepared an update of its Multilateral Debt Relief Initiative (MDRI) assessment, which will be presented to the World Bank Board, in June 2006.

16. Oil. The Mauritanian government recently adhered to the Extractive Industry Transparency Initiative (EITI). The Bank and Fund actively support the authorities in the implementation of the EITI and in the management of oil revenues, focusing in particular on the following topics: (i) the creation of a single oil account (SOA) - where all government revenues that are derived from hydrocarbon production should be directly deposited managed by the BCM; (ii) the treatment of oil in the budget laws, which should indicate the portion of resources held by the SOA to be either saved or used to finance part of the non-oil budget deficit; and (iii) the auditing of SOA accounts by an independent auditor on a quarterly basis. Good progress has been realized in these areas, notably on the establishment of the oil account - which is now operational - and the delegation of powers from the Ministry of Finance to the BCM. Further progress is required to elaborate, finalize and enact the National Hydrocarbon Law. The World Bank Treasury is also providing technical assistance to the BCM in the area of reserve management, following a specific request from the authorities and in agreement with the IMF.

17. Financial Sector Reform. As part of the CAS, the Bank, in close collaboration with the Fund, is helping the authorities in improving financial sector intermediation for private sector development, and mobilizing savings, while promoting competition in the financial sector. A Financial Sector Study was completed in 2004. A joint Bank/IMF in-depth review of the financial sector (FSAP) took place in late March/early April 2006 and found that:

(i) Financial services in Mauritania are underdeveloped, with the banking system still accounting for an overwhelming share of the financial sector; (ii) Credit risk, including risk concentration, is Mauritanian banks' main vulnerability; (iii) Banking supervision has been strengthened but the regulatory framework still lags significantly behind international standards; and (iv) Non-bank financial services (e.g. microfinance, insurance) are at an early stage of development. The authorities have asked the bank to assist with the implementation of the FSAP proposed action plan and a proposed project is under preparation for delivery in FY08. 
18. Poverty and Social Impact Analysis (PSIA). The Bank and Fund have agreed to review closely the poverty and social impact of reforms that are being implemented. To date, benefit-incidence analysis has been conducted in the health and education sectors to assess the welfare impact of public spending on different groups of people: this analysis will be updated with the data from the recently completed EPCV 2004. In the mining sector, PSIA is being conducted to evaluate the impact of reducing the services provided by the national mining company (SNIM) to different groups of people. Additional poverty-related analytical work includes: (i) a survey on the dynamics of rural labor markets (finalized); and (iv) the elaboration of poverty maps (ongoing).

- Contact Persons. Questions may be addressed to Mr. Nils Tcheyan, Acting Country Director, ext. 38445; Mr. Francois Rantrua, Country Manager, ext. 5353-312, or Mr. Nicola Pontara, Senior Economist, ext. 5873-185. 


\section{APPENDiX III. MAURITANIA: StatistiCAL ISSUES As of May 25, 2006}

Despite the efforts invested by the authorities in the revision of the historic data, the data compilation and reporting system remains weak and suffers from staffing shortages. While data provision to the Fund is now broadly adequate for surveillance purposes, shortcomings in the national accounts and balance of payments statistics hamper analysis. However the authorities are now committed to maintaining full data transparency in all sectors, in line with their participation in the GDDS, which began in September 2004. The National Statistics Council (CNS) called for by the Statistics Law of January 2005 was established in February 2006.

\section{Real sector}

National accounts data require substantial further improvement. Revisions of national accounts have been under way for several years to take advantage of methodological refinements in estimates of informal sector activity. The new set of national accounts follows 1993 SNA and uses 1998 as a base year. Thus far, national accounts from 1998 to 2001 were finalized. The National Statistical Office (ONS) has produced preliminary estimates for 2002-04. Nevertheless, technical assistance is still needed to conduct statistical surveys (current estimates are based on data reported by tax authorities) and prepare estimates for the informal sector.

Based on results from the 2001 household expenditure survey and with the assistance of AFRISTAT, the ONS started to publish in May 2004 a new CPI index with an updated consumption basket, covering a wider range of markets albeit with geographical coverage still limited to Nouakchott.

\section{Government finance}

There are still no monthly or annual government finance statistics being reported to STA. With ongoing methodological improvements, the monthly statements of treasury accounts could provide the basis for reporting budgetary central government statistics to STA. The monthly Treasury balance is reconciled with the Treasury accounts at the BCM. It constitutes the basis for a monthly fiscal reporting table (TOFE) that is provided to the Minister of Finance with a maximum lag of one month. Expenditures are recorded on a payment order basis, and since April 2006, on the basis of a functional classification of expenditure, thus allowing for monthly tracking of the execution of poverty-reducing expenditure. A detailed quarterly budget execution report will be published on the Treasury website (www.tresor.mr).

The verification of fiscal data is an ongoing process. Tax auditing should improve following the government's decision to establish a single tax identifier for enterprises, which would allow the crosschecking of data available in various administrations. For its part, the General Directorate of Customs will improve its import verification methods. The Office of the Minister of Finance has produced in April 2006 a first report on the reconciliation of discrepancies between import valuations by Customs and the values reported by the Société

Générale de Surveillance (SGS). On the expenditures side, a review of the payroll database to 
identify and eventually eliminate ghost workers is still underway. The 2006 budget includes all expenditures previously financed without budgetary appropriations. A substantial proportion of budget appropriations previously allocated to centralized expenditures has been broken down by ministry. Moreover, the budget document presently shows operating and (domestically financed) capital expenditure together for each ministerial department.

\section{Money and banking}

Data on monetary authorities and deposit money banks are reported on an irregular basis to STA. The most recent monetary data received and published in the IFS are for March 2004. However, starting in July 2006, the BCM intends to publish monetary accounts on a monthly basis. An STA expert provided in November 2005 detailed recommendations on the way central bank statistics should be derived from the central bank accounts, so as to ensure accurate data reporting to the Fund. The implementation of those of the January 2004 IMF safeguards assessment mission will continue, particularly the recommendations relating to the improvement in the presentation of the central bank accounts. The final audit reports of the BCM's 2003, 2004, and 2005 financial statements have been released to staff and are now broadly consistent with the revised data. These report (and reports for future years) will be published on the BCM's official website.

\section{Balance of payments}

The balance of payments is compiled based on the foreign exchange records of the central bank, which requires commercial banks to regularly report details of external transactions they conduct on behalf of their customers. This information is supplemented by a limited number of secondary sources, including customs data, external debt statistics, and data communicated directly by the state-owned iron ore company. However, significant weaknesses in the balance of payments remain, in particular concerning nonmining exports, services, transfers, foreign direct investment, and short-term capital flows. A recent balance of payments statistics mission (April 5-18, 2006) noted that the central bank's foreign exchange record did not provide an accurate picture of external transactions undertaken

during the reporting period. Moreover, there is no systematic effort to collect data on tourism receipts, certain types of transfers, and foreign direct investment. As a result, many BOP items are routinely based entirely on estimates. Despite recommendations from earlier missions, the balance of payments continues to be presented in line with the Fourth Edition (1977) of the Balance of Payments Statistics Manual. The 2006 mission proposed several measures for improving the quality of commercial banks' reporting on external transactions. It also advised the authorities on how to obtain additional and better data on services, transfers, and foreign direct investment, notably in the oil and mining sectors. In terms of the organizational setup, the mission recommended that the ONS develop competencies in the area of the trade balance, while the BCM should clarify and consolidate its internal responsibilities for the compilation of balance of payments statistics. 
Poverty and social indicators

The household expenditure surveys, conducted at the national level for the years 1990, 1996, and 2000, are a main source for building poverty profiles and setting poverty reduction targets. A limited survey was conducted in 2003 by the ONS in the capital city Nouakchott (which hosts about one-third of the country's population). A new Poverty Reduction Strategy Paper (PRSP) covering the period 2006-10, currently under preparation, will present revised poverty indicators. 


\section{MAURITANIA: TABLE OF COMMON INDICATORS REQUIRED FOR SURVEILLANCE As of May 25, 2006}

\begin{tabular}{|c|c|c|c|c|c|}
\hline & $\begin{array}{c}\text { Date of } \\
\text { latest } \\
\text { observation }\end{array}$ & Date received & $\begin{array}{c}\text { Frequency } \\
\text { of } \\
\text { Data }^{6}\end{array}$ & $\begin{array}{l}\text { Frequency } \\
\text { of } \\
\text { Reporting }\end{array}$ & $\begin{array}{c}\text { Frequency } \\
\text { of } \\
\text { publication }^{6}\end{array}$ \\
\hline Exchange Rates & Apr. 2006 & May 2006 & $\mathrm{D}$ & $\mathrm{D}$ & $\mathrm{D}$ \\
\hline $\begin{array}{l}\text { International Reserve Assets and Reserve Liabilities } \\
\text { of the Monetary Authorities } 1\end{array}$ & Apr. 2006 & May 2006 & M & M & NA \\
\hline Reserve/Base Money & Apr. 2006 & May 2006 & $\mathrm{M}$ & M & NA \\
\hline Broad Money & Apr. 2006 & May 2006 & M & M & NA \\
\hline Central Bank Balance Sheet & Apr. 2006 & May 2006 & $\mathrm{M}$ & M & NA \\
\hline Consolidated Balance Sheet of the Banking System & Apr. 2006 & May 2006 & M & M & NA \\
\hline Interest Rates $^{2}$ & Apr. 2006 & May 2006 & $\mathrm{~W}$ & W & W \\
\hline Consumer Price Index & Apr. 2006 & May 2006 & M & M & M \\
\hline $\begin{array}{l}\text { Revenue, Expenditure, Balance and Composition of } \\
\text { Financing }{ }^{3} \text { - General Government }\end{array}$ & NA & NA & NA & NA & NA \\
\hline $\begin{array}{l}\text { Revenue, Expenditure, Balance and Composition of } \\
\text { Financing } 3 \text { - Central Government }\end{array}$ & Apr. 2006 & May 2006 & $\mathrm{M}$ & M & I \\
\hline $\begin{array}{l}\text { Stocks of Central Government and Central } \\
\text { Government-Guaranteed Debt }\end{array}$ & Dec 2005 & January 2006 & A & A & $\mathrm{I}$ \\
\hline External Current Balance & Mar. 2006 & April 2006 & Q & Q & $\mathrm{I}$ \\
\hline Exports and Imports of Goods and Services & Mar. 2006 & April 2006 & Q & Q & $\mathrm{I}$ \\
\hline GDP/GNP & $2004^{7}$ & April 2006 & A & A & I \\
\hline Gross External Debt & Dec 2005 & January 2006 & $\mathrm{~A}$ & A & I \\
\hline
\end{tabular}

${ }^{1}$ Includes reserve assets pledged or otherwise encumbered as well as net derivative positions.

${ }^{2}$ Both market-based and officially-determined, including discount rates, money market rates, rates on treasury bills, notes and bonds.

${ }^{3}$ Foreign, domestic bank, and domestic nonbank financing.

${ }^{4}$ The general government consists of the central government (budgetary funds, extra budgetary funds, and social security funds) and state and local governments.

${ }^{5}$ Including currency and maturity composition.

${ }^{6}$ Daily (D), Weekly (W), Monthly (M), Quarterly (Q), Annually (A), Irregular (I), Not Available (NA).

${ }^{7}$ Preliminary. 


\section{Statement by the IMF Staff Representative June 21, 2006}

1. This statement summarizes information, which has become available since the staff report was circulated to the Executive Board on June 7, 2006. It does not change the thrust of the staff appraisal.

2. The noncomplying disbursements have been repaid. The second installment of SDR 10.14 million with SDR 6,529 as interest was paid on June 12, 2006, three days earlier than expected.

3. Preliminary data indicate that macroeconomic performance through May 2006 was in line with the staff-monitored program objectives for the first half of 2006 . The basic nonoil deficit through end-May appears to be contained at one percent of non-oil annual GDP below the end-June target of 2.7 percent; base money increased by only 8.6 percent during January-May, well below the 15.3 percent projected for the first six months; gross foreign assets of the BCM reached US\$63.7 million at end-May (compared with the end-June projection of $\$ 65.4$ million) and the parallel market premium over the official UM/US\$ exchange rate stood at $1 / 4$ percent through mid-June. With the CPI rising by 0.9 percent in May_-somewhat less than anticipated given recent domestic petroleum price increases12-month inflation at end-May receded to 5.1 percent (from 5.3 percent at end-April); this strengthened the prospect for attaining the end-2006 inflation objective of 8.1 percent. The authorities have approved the new production sharing contracts for the Chinguetti zone (signed on June 6, 2006), which implies that the signature bonus of US\$100 million would be disbursed by end-June 2006, a month earlier than projected in the staff report.

4. Implementation of structural reforms is proceeding as scheduled. The final audit report for the BCM's end-2005 accounts has been transmitted to the Fund and is expected to be published on the Internet by end-June. The national committee for the implementation of the Extractive Industries Transparency Initiative took further steps in preparation for the first annual 2006 report, scheduled for publication by end-September 2006. National consultations on the draft PRSP were held during June 5-7, 2006. 
Press Release No. 06/137

FOR IMMEDIATE RELEASE

June 21, 2006
International Monetary Fund

Washington, D.C. 20431 USA

\section{IMF Executive Board Approves 100 percent Debt Relief for Mauritania Under the Multilateral Debt Relief Initiative}

The Executive Board of the International Monetary Fund (IMF) approved today 100 percent debt relief for Mauritania under the Multilateral Debt Relief Initiative (MDRI) amounting to SDR 32.9 million (about US\$49 million), including SDR 2.7 million (about US\$4 million) of assistance remaining under the enhanced Heavily Indebted Poor Countries (HIPC) Initiative. The Board's decision brings to 21 the number of countries that have received 100 percent relief from the IMF under the MDRI, and the total amount of relief granted by the Fund under the initiative to SDR 2.54 billion (about US\$3.67 billion).

Mauritania has implemented all the remedial actions that were required for MDRI qualification, including the resolution of data issues, six months of satisfactory macroeconomic performance, and remedial actions in the areas of budget formulation, execution, and reporting (see Press Release No. 05/308).

"Mauritania has made important strides since last autumn, including the resolution of data issues and the implementation of reforms in the management of public finances, prominently in the context of oil revenues and the tracking of social expenditures," said IMF Deputy Managing Director Agustín Carstens, who chaired the Executive Board session on Mauritania. "These are steps that will help Mauritania reach its ambitious poverty-reduction targets under the Millennium Development Goals. For our part, the IMF is supporting the government's efforts through sweeping debt relief."

The purpose of the MDRI is to accelerate eligible countries' progress towards the Millennium Development Goals by providing relief on their eligible debt to the IMF and by ensuring that the corresponding resources are allocated to poverty reduction (see Public Information Notice No. $\underline{05 / 164)}$. 


\section{Statement by Damian Ondo Mañe, Executive Director for the Islamic Republic of Mauritania June 21, 2006}

During the preliminary assessment of the first group of countries eligible for relief under the MDRI, in December 21, 2005, the Executive Board determined that Mauritania was not in a position to qualify immediately for debt relief because the country's macroeconomic performance had deteriorated substantially since it was assessed at the completion point. Furthermore, serious data issues had plagued Mauritania's relations with the Fund. The Board estimated that prior to assessing Mauritania's qualification to the MDRI, the authorities would need to resolve pending data issues and take remedial actions in the area of public expenditure management. Sound macroeconomic policies over a period of six months would also be necessary. My authorities have addressed these issues within the current SMP framework covering the period January-June 2006.

Today, Mauritania has complied with all the recommendations of the Executive Board. The new government, in place since August 2005, has made transparency and good governance a priority in its reforms agenda. It has taken strong measures to solve the data issues, and has implemented sound policies with a high degree of ownership. The authorities have also repaid the two disbursements that were determined to be noncomplying by the Executive Board on March 27, 2006. The first installment of SDR 2 million was repaid within the month following the Board decision, and the second installment of SDR 10.14 million was repaid on June 12, 2006. I would like, on behalf of my authorities, to express my deep appreciation to staff and management for their close cooperation and active support to Mauritania and their valuable assistance in helping my authorities solve all pending issues and ensuring a prompt qualification of Mauritania to the MDRI.

My Mauritanian authorities are confident that the progress achieved so far in stabilizing the economy -and in such a short period-, will give assurances to the international community of my authorities' sincerity and determination to put the issue of past data behind them, and move on to address the considerable challenges ahead. They welcome in this regard the resumption of the European Union (EU) assistance to Mauritania. My authorities are also hopeful that the steps they have taken will qualify them for debt relief under the MDRI.

\section{Data Revision and Past Economic Performance}

The authorities have prepared a report that reassesses past macroeconomic performance based on revised data over the 1992-2004 period. Major efforts are now under way, with the assistance of the IMF, to ensure that data reporting will remain reliable. In the 
same vein, the authorities have put an end to extra-budgetary spending and to the Central Bank financing of the fiscal deficit. The report, however, is still preliminary. Additional work is under way to explain some of the issues raised by staff in the report.

\section{Stabilization of the Economy and Policies under the SMP}

In 2005, real GDP growth rose to $5 \frac{1}{2}$ percent mainly due to a surge in investment associated with the imminence of oil production. The implementation of tight monetary and fiscal policies in the last part of the year, resulted in a declined in inflation. The slight deterioration of the fiscal deficit in 2005, was further contained by the interruption of extrabudgetary spending from September 2005. The parallel market premium disappeared by the end of the year, as a result of the improved confidence in the national currency resulting from the on-coming of oil production while the exchange rate appreciated moderately. The improvement in the external position has benefited from higher commodity prices worldwide, and an increase in FDIs attracted by the booming oil and mining sectors. Foreign exchange reserves, however, remained low in 2005, and are expected to rise slowly from 1.4 month of import cover at end-2006, to 3 months in 2008.

For the first quarter of 2006, tight budgetary and monetary policies under the SMP, have helped further stabilize the economy. Fiscal performance, in particular, was strong and spending was maintained within the SMP limits. Efforts were made to improve PEM, including through the preparation of a medium-term expenditure framework. In addition, the authorities have adopted a functional classification of the budget that will enable, notably, the tracking of poverty reducing expenditure.

For the remainder of the year, real GDP growth in the non-oil sector is expected to increase to 6.8 percent. Oil revenues and fiscal discipline will improve the fiscal stance significantly, while allowing for a substantial increase in poverty reducing expenditure. Government borrowing from the banking sector through the emission of treasury bills will help to keep monetary policy tight, until oil receipts reduce the government's need for financing from the banking sector. To prevent a rapid spending of oil revenues, efforts are being made to promote a transparent and sound management of oil resources. In this regard, Mauritania has adhered to the EITI since September 2005, and the authorities have created a committee composed of representative of all relevant stakeholders to monitor the implementation of the initiative.

To further enable a sound management of oil resources, a single oil account has also been established at the Banque de France, where all government oil revenues will be deposited -the Hydrocarbon Revenue Fund. Oil resources will be channeled into this fund and will be used notably to smooth out public spending if prices were to fall. A law for the management of these resources is also under preparation. The additional revenues expected 
by the end of the month of June 2006, from the revision of the production sharing contract with the oil company Woodside, will also be deposited in the hydrocarbon fund and will be used to repay the government's domestic debt, including its debt vis-à-vis the Central Bank. This will contribute to strengthen the Central Bank's weak foreign exchange reserves. Looking forward, saving part of the oil resources would also help to alleviate a likely appreciation of the exchange rate that could adversely affect the competitiveness of the nonoil sector. Indeed, there are increasing signs that other factors are already affecting Mauritania's competitiveness and hindering the development of important sectors of the economy, including the fishing sector. These include the limited capacity of the national electricity company and the enforcement of the international oil price pass-through mechanism. My authorities will continue to work closely with the IMF and the World Bank to discuss the best possible use of oil resources with the objective to promote growth and fight poverty.

On the structural front, the government, is preparing the introduction of a foreign exchange market, scheduled for end-2006. The authorities have defined a timetable for the introduction of the foreign exchange market that takes into account the projected improvement in foreign exchange reserves. My authorities believe that a minimum of 2 months of import cover would be necessary to launch this market on a sound and credible basis. Also essential for the start of the foreign exchange market are the current efforts by my authorities to repay private sector external arrears. Moreover, the requirement to surrender to the Central Bank part of the foreign exchange proceeds from fishery exports will also be phased out gradually, as foreign exchange reserves improve, and will be eliminated before the new foreign exchange market is operational. However, the Central Bank intends -at least in its early stages-, to monitor real exchange rate movements, notably to avoid a potentially rapid appreciation of the national currency resulting from large inflows of capital associated with oil- and, other mining-related activities that could adversely impact the competitiveness of the non-oil sector. A close monitoring of the exchange rate by the Central Bank will also be needed since demand of foreign currency by market participants will most likely exceed supply, for a certain period of time. This underscores the need to put in place appropriate liquidity management instruments at the Central Bank.

My authorities have been associated to the current negotiations between the EU and ECOWAS, on a new Economic Partnership Agreement (EPA). The discussions are set in the broader context of the revision of the trade regime between the EU and ACP countries within the 2000 Cotonou Agreement. Both parties, EU and ACP countries, are required to put in place a WTO-compatible alternative to these agreements, by 2008. My authorities are aware of the risks involved (reciprocity) but also note the advantages associated to the EPA (potential increase in EU assistance). They will monitor carefully the potential impact on Mauritania's economy of the changes that would result from these negotiations. 


\section{Economic Prospects and Challenges}

Mauritania's economic prospects are encouraging. Notwithstanding a temporary slowdown in the volume of oil produced-compared to the initial target of 75,000 barrels per day-, international oil prices remain high and the recent revision of the production sharing contracts with Woodside will further increase substantially Mauritania's oil revenues for 2006.

Debt relief under the MDRI -highly anticipated by the Mauritanian population-, will also provide needed resources to assist the authorities in their financial efforts to reduce poverty and accelerate progress towards achieving the MDGs.

The national iron ore company (SNIM) plans to increase substantially its investments in the medium-term, against the backdrop of rising iron ore prices. Copper and gold production have also started in 2006. However, prospects in the fishing sector remain uncertain, with the expiration of the fishing agreement with the EU on July 31, 2006. In case Mauritania does not reach an agreement with the EU by that date, my authorities have considered alternative solutions that they have shared with staff. They intend notably to launch international tenders of fishing licenses to compensate for the potential loss in EU revenues.

How to best manage the abundant resources expected in the coming years, is one of the most important challenges that my authorities will face. Capacity remains limited and the risks associated with the rapid rise in foreign exchange revenues on the competitiveness of the economy are high. My authorities are aware of these risks and will continue to work closely with the IMF and the World Bank to discuss possible ways to alleviate them. They agree that saving oil resources is essential to mitigate these risks. They are also committed to use part of these resources to accelerate poverty reduction and achieve more rapidly the MDGs. In this regard, they are completing their second PRSP - which is at an advanced stage-, covering the period 2006-10, through a broad-based participatory process. The new PRSP redefines Mauritania's development objectives through 2015 -target date of the MDGs-, and takes into account the substantial increase in projected foreign exchange inflows, and their use in the fight against poverty.

Other challenges include the need to diversify the economy away from its narrow dependence on a few exports commodities, and reduce its vulnerability to potential shocks, including the decline in world commodity prices that could severely affect the economy. Avoiding a new debt build-up, following MDRI debt relief, is also crucial. Accordingly, my authorities will develop a medium-term debt management strategy. While they acknowledge that the responsibility of a sound debt management policy is ultimately in their hands, advice and technical assistance from the Fund and other partners is essential. Also in this context, they will pursue their efforts to reach agreements with all bilateral creditors that would 
provide debt relief on terms comparable to the one provided by Mauritania's Paris Club creditors HIPC debt relief. They have asked the IMF to assist them in solving the issues raised in the staff report.

\section{Conclusion}

It is my authorities' hope that the satisfactory implementation of the SMP, by end-June 2006 -to which they remain firmly committed-, and the rapid progress made in implementing key reforms, will pave the way soon, to a new PRGF-supported program. Such an arrangement would help consolidate the important achievements made so far under the SMP.

Mauritania's resources prospects remain good and my authorities will continue to implement a prudent management of oil revenues. But the low level of foreign exchange reserves expected to endure a few more years, along with the fragile current transition towards good governance and transparency, and the country's vulnerability to climatic and price commodity shocks, still deserves the financial support of the IMF and the international community.

In light of the authorities' compliance with the Board's recommendations, the remedial actions taken and the strong policy performance under the SMP, I would like to request the support of the Board for a declaration of Mauritania's qualification for debt relief under the MDRI.

Finally, my authorities also request that the Executive Board grant them an extension of the current exchange restrictions under Article VIII, Section 2 (a), until October 31, 2006. The currently weak foreign exchange reserves make it difficult to eliminate foreign exchange rationing for the time being. Foreign exchange rationing will, however, be eliminated by end-October 2006 with the improvement of Mauritania's foreign exchange reserves. 


\section{INTERNATIONAL MONETARY FUND}

Public Information Notice No. 06/74 FOR IMMEDIATE RELEASE
International Monetary Fund

700 19th Street, NW

Washington, D. C. 20431 USA

\section{IMF Concludes 2006 Article IV Consultation with Mauritania}

On June 21, 2006, the Executive Board of the International Monetary Fund (IMF) concluded the Article IV consultation with Mauritania. ${ }^{1}$

\section{Background}

The Mauritanian transition authorities, in office since the regime change in August 2005, implemented an impressive policy shift toward transparency and good governance. They have decided to fully cooperate on the data issues that had plagued the relations with the Fund since early 2004 and revised most economic and financial data that had been provided to the Fund since 1992. The revised data show substantially looser macroeconomic fiscal and monetary policies, and lower official reserve accumulation than previously reported to the Fund. The long-lasting provision of erroneous data in the past led to misinformed policy advice, which proved costly for the country. ${ }^{2}$

The new authorities swiftly embarked on a course of macroeconomic stabilization and reforms. They banned the previous practices of off-budget spending and aligned the fiscal stance with the tight monetary stance adopted by the Central Bank of Mauritania (BCM) since mid-2004, founded on its no government deficit financing policy. As a result, inflation returned to single-digit levels in the last quarter of 2005 and Mauritania's external position-which has also benefited from improving terms of trade since 2005started to strengthen.

In February 2006, Mauritania became an exporter of crude oil from an offshore field, with daily production averaging 54,000 barrels over the past three months. The oil

\footnotetext{
${ }^{1}$ Under Article IV of the IMF's Articles of Agreement, the IMF holds bilateral discussions with members, usually every year. A staff team visits the country, collects economic and financial information, and discusses with officials the country's economic developments and policies. On return to headquarters, the staff prepares a report, which forms the basis for discussion by the Executive Board. At the conclusion of the discussion, the Managing Director, as Chairman of the Board, summarizes the views of Executive Directors, and this summary is transmitted to the country's authorities.

${ }^{2}$ In addition, because of misreporting data to the Fund under the 1999-2002 PRGF arrangement, Mauritania repaid to the Fund on April 26 and June 12 two noncomplying disbursements which had been made in June and December 2002 (see press release No. 06/64).
} 
investment-related activity helped maintain real growth in 2005 above 5 percent and, with the arrival of oil production, real growth is expected to attain nearly 20 percent in 2006. Non-oil real GDP growth (projected at $6 \frac{1}{2}$ percent) will be supported by new mining activity (copper and gold) and a substantial increase in public investment. Mauritania's improved external position would allow for a buildup of international reserves to nearly $1 \frac{1}{2}$ months of imports at end-2006.

The authorities have launched a staff-monitored program (SMP) covering the first half of 2006, to maintain the disinflation and fiscal consolidation momentum and implement key reforms in the areas of data transparency, oil revenue management, and public expenditure management. The SMP is firmly on track. Fiscal and monetary aggregates were well within the end-March 2006 targets and all structural indicators have been realized. Under the program, Mauritania proceeded with a timely closure of the 2005 supplementary budget, reduced domestic payment arrears, initiated a monthly reporting of the central government financial operations based on reconciled Treasury and BCM data, and adopted a functional classification of expenditure enabling the identification and tracking of poverty-reducing spending. The authorities also made steps toward establishing an efficient and transparent management of oil revenues, through adherence to the Extractive Industries Transparency Initiative and the creation of the National Hydrocarbon Revenue Fund (FNRH), which is now operational. Further steps are expected, including the publication of the production sharing contracts, quarterly reports on production and exports, and the certified FNRH statements, which shall be audited on a regular basis by a reputable international firm. Satisfactory implementation of the SMP is expected to pave the way for a new PRGF-supported program.

Mauritania has implemented all the remedial actions requested to qualify for the Multilateral Debt Relief Initiative (MDRI), including the resolution of the data issues, six months of satisfactory macroeconomic performance, and implementation of the remedial actions in budget formulation, execution, and reporting. Mauritania's debt relief from the IMF, the World Bank's International Development Association, and the African Development Fund of the African Development Bank, would amount to about US $\$ 400$ million in net present value (NPV) terms, representing about 36.5 percent of the estimated NPV of public external debt at end-2006. The purpose of the MDRI is to accelerate eligible countries' progress towards the Millennium Development Goals by cancelling their debt to the above-mentioned creditors, and by ensuring that the corresponding resources are allocated to poverty reduction.

The authorities have decided to take advantage of the strong fiscal and external outlook for 2006 to further consolidate public finances and liberalize the foreign exchange system. The expected oil revenue and the maintenance of fiscal discipline are estimated to result in an overall fiscal surplus of some 10 percent of non-oil GDP, to be largely channeled toward the reduction of domestic government debt and payment arrears. The $\mathrm{BCM}$ is expected to remove the remaining restrictions under Article VIII of the Fund's Articles of Agreement and to allow for larger flexibility in exchange rate determination through the launching of an interbank currency auction market. 


\section{Executive Board Assessment}

Executive Directors commended the substantial progress achieved in recent months by the Mauritanian authorities in improving macroeconomic policies, budget formulation, and governance and transparency, and in resolving the data issues that had undermined relations with the Fund. They viewed these steps, as well as Mauritania's full and timely repayment of the two noncomplying disbursements under the 1999-2002 PRGF arrangement, as essential building blocks for the close cooperation between Mauritania and the international community that will be needed to exploit fully Mauritania's improved growth and development prospects. In the period ahead, the authorities should focus on consolidating macroeconomic stability and strengthening the external position through prudent budgetary use of new oil revenue, while avoiding recourse to central bank budget financing.

Directors underscored that tight and well coordinated fiscal and monetary policies will need to be at the center of efforts to consolidate the macroeconomic stabilization and achieve the ambitious official reserves and disinflation objectives set for 2006 . In this regard, they endorsed the authorities' plan to adhere to the original budgetary spending ceilings despite higher-than-budgeted oil revenue, while using the oil revenue for the reduction of domestic debt. Directors urged the authorities to provide a durable solution for the two parastatals in need of rehabilitation without jeopardizing the 2006 fiscal objectives.

Directors were encouraged by improvements in public expenditure management. They welcomed the timeliness and accuracy of public finance reporting based on the Treasury records and their regular reconciliation with the central bank data. Directors strongly endorsed the preparation of a medium-term expenditure framework ahead of the budget preparation cycle, and underscored the importance of sustaining the momentum of recent reforms by enhancing competition in the public procurement system and by further tightening expenditure controls, including through the planned computerization of the spending authorization circuit.

Directors welcomed the recent tightening of monetary policy, noting that the interest rate increases had strengthened the central bank's credibility in pursuing price stability. They recommended careful monitoring of international and domestic price pressures to control the risks to the authorities' disinflation objectives. Directors also recommended the development of alternative policy instruments to facilitate more active liquidity management.

Directors underscored that a well-prepared move toward a more flexible exchange rate policy would help contain inflationary pressures, particularly in light of the improved external outlook. They supported the authorities' planned steps toward the introduction of foreign exchange auctions, which will eliminate the foreign exchange rationing system and ensure free access to foreign exchange for current international transactions. 
Directors noted the implementation of all remedial actions for Multilateral Debt Relief Initiative (MDRI) qualification, and agreed that Mauritania now qualifies for debt relief under the MDRI. They welcomed the authorities' plan to develop a medium-term debt management strategy. Directors urged the authorities to avoid accumulating new non-concessional external debt, and non-Paris Club creditors to conclude the remaining bilateral agreements. They noted that adequate monitoring mechanisms are in place to safeguard the use of MDRI resources, and that the introduction of the new functional classification of expenditure will enhance the targeting and tracking of poverty reducing outlays.

Directors encouraged the authorities to build on the progress achieved in ensuring sound and transparent management of oil revenues, including through the implementation of the Extractive Industries Transparency Initiative and the national hydrocarbon revenue fund. Directors stressed the importance of proper and timely reporting and auditing mechanisms, including through the appointment of independent and reputable auditors, and welcomed the planned publication of oil production, sales, and revenue data.

Directors emphasized that the medium-term framework should focus on preserving macroeconomic stability and on a prudent use of oil revenue, thereby allowing Mauritania to realize its growth and poverty reduction objectives. They endorsed the authorities' efforts to develop a sustainable poverty reduction strategy for 2006-10 centered on the market-based development of labor-intensive industries in which Mauritania enjoys comparative advantage. Directors noted that enhancing productivity in the non-oil sectors and safeguarding their competitiveness will require improvements in the business climate, efficient public investments, prudent wage policies, and an open trade policy. They also called on the authorities to strengthen the financial sector regulatory framework, and commended the authorities for the steps taken toward establishing a comprehensive AML/CFT framework.

Public Information Notices (PINs) form part of the IMF's efforts to promote transparency of the IMF's views and analysis of economic developments and policies. With the consent of the country (or countries) concerned, PINs are issued after Executive Board discussions of Article IV consultations with member countries, of its surveillance of developments at the regional level, of post-program monitoring, and of ex post assessments of member countries with longer-term program engagements. PINs are also issued after Executive Board discussions of general policy matters, unless otherwise decided by the Executive Board in a particular case. 


\begin{tabular}{|c|c|c|c|c|c|}
\hline 2001 & 2002 & 2003 & 2004 & 2005 & 2006 \\
\hline \multicolumn{4}{|c|}{ Revised } & Prel. & Proj. \\
\hline
\end{tabular}

National income and prices

GDP at constant prices 1/

Non-oil GDP at constant prices

GDP deflator 1/

Non-oil GDP deflator

Consumer price index (period average)

Consumer price index (end of period)

\section{External sector}

Exports of goods, f.o.b. (percentage change in U.S. dollars)

Of which: non-oil

Imports of goods, f.o.b. (percentage change in U.S. dollars)

Imports of goods, f.o.b. (percentage change in U.S. dollars) 2/

Official transfers (in percent of GDP)

Current account balance (in percent of GDP)

Current account balance (in percent of GDP) 2/

Overall balance (in percent of GDP)

\section{Official reserves}

Gross official reserves (in millions of U.S. dollars, end of period) 3/

Idem, in months of following year's imports of goods and services 2/

\section{Money and credit}

Money and quasi-money

Currency in circulation

\section{Consolidated government operations}

Revenue and grants

Revenue and grants (excluding oil)

Idem, excluding grants

Oil revenue 4/

Expenditure and net lending

Overall balance including grants

Overall non-oil balance excluding grants

Overall non-oil balance including grants

\section{Memorandum items:}

Ouguiya/U.S. dollar exchange rate (end of period)

Exports, f.o.b. (in millions of U.S. dollars)

Imports, f.o.b. (in millions of U.S. dollars) 2/

Nominal GDP (in billions of ouguiya)

Nominal non-oil GDP (in billions of ouguiya)

Nominal GDP (in millions of U.S. dollars)

Population (in millions)

GDP per capita (in U.S. dollars)

REER (12-month percentage change; end of period) 5/

(Percentage changes; unless otherwise indicated)

$\begin{array}{cccccc}2.9 & 1.1 & 5.6 & 5.2 & 5.4 & 19.4 \\ 2.9 & 1.1 & 5.6 & 5.2 & 5.4 & 6.8 \\ 7.9 & 7.8 & 2.5 & 11.5 & 18.9 & 44.3 \\ 7.9 & 7.8 & 2.5 & 11.5 & 18.9 & 8.7 \\ 7.7 & 5.4 & 5.3 & 10.4 & 12.1 & 6.5 \\ 4.1 & 8.4 & 2.9 & 16.1 & 5.8 & 8.1 \\ & & & & & \\ 0.2 & -6.6 & -4.1 & 38.1 & 37.4 & 213.2 \\ 0.2 & -6.6 & -4.1 & 38.1 & 37.4 & 27.9 \\ 2.4 & -7.3 & 25.7 & 70.3 & 50.3 & -12.9 \\ -7.0 & -7.6 & 22.1 & 33.7 & 14.7 & 17.4 \\ 6.9 & 5.1 & 6.9 & 4.1 & 3.8 & 2.5 \\ -11.7 & 3.0 & -13.6 & -34.6 & -49.9 & 3.5 \\ -6.7 & 7.6 & -7.1 & -11.9 & -7.8 & -8.9 \\ -7.6 & -2.8 & -9.9 & -7.3 & -3.9 & 4.8 \\ & & & & & \\ 40 & 74 & 32 & 39 & 70 & 152 \\ 0.9 & 1.4 & 0.4 & 0.5 & 0.7 & 1.4 \\ & & & & & \\ 34.3 & 23.8 & 25.5 & 13.5 & 14.6 & 15.8 \\ 17.6 & 17.7 & 47.5 & -3.4 & 14.8 & 12.8\end{array}$

(In percent of non-oil GDP)

\begin{tabular}{cccccc}
24.7 & 34.8 & 35.4 & 32.9 & 26.4 & 43.0 \\
24.7 & 34.8 & 35.4 & 32.9 & 26.4 & 26.1 \\
20.7 & 30.4 & 30.7 & 29.7 & 24.4 & 23.6 \\
$\ldots$ & $\ldots$ & $\ldots$ & $\ldots$ & $\ldots$ & 17.0 \\
35.0 & 37.6 & 47.2 & 37.7 & 33.5 & 32.6 \\
-10.3 & -2.9 & -11.8 & -4.8 & -7.0 & 10.5 \\
-14.3 & -7.2 & -16.4 & -8.0 & -9.1 & -8.9 \\
-10.3 & -2.9 & -11.8 & -4.8 & -7.0 & -6.5 \\
& & & & & \\
264.1 & 268.7 & 265.6 & 256.2 & 268.6 & $\ldots$ \\
355 & 332 & 318 & 440 & 604 & 1,892 \\
415 & 383 & 468 & 625 & 718 & 843 \\
287 & 312 & 338 & 397 & 497 & 857 \\
$\ldots$ & $\ldots$ & $\ldots$ & $\ldots$ & $\ldots$ & 577 \\
1,122 & 1,150 & 1,285 & 1,495 & 1,871 & 3,189 \\
2.57 & 2.63 & 2.69 & 2.76 & 2.82 & 2.89 \\
437 & 437 & 477 & 542 & 663 & 1,103 \\
4.5 & -9.3 & -13.4 & 8.1 & 8.7 & 0.3 \\
\hline
\end{tabular}

Sources: Mauritanian authorities; and Fund staff estimates and projections.

1/ The large increase in the GDP deflator in 2006 (and the relatively low increase in real GDP for this year) reflect the authorities' choice of 1998 as the base year for the calculation of national accounts at constant prices. Oil prices were at a low in 1998.

2/ Excluding oil exploration/production and other (copper, gold) mining-related activities.

3/ Excluding oil account.

4/ Including oil signature bonuses.

5/ In 2006: estimates through end-May. 